\title{
1
}

\section{Introduction: Researching Memory and Generation}

Danica, Aida and Darko spent (most of) their lives in the city of Mostar. However, they grew up in three different countries: while Danica (born 1926) spent her childhood in the Kingdom of Serbs, Croats and Slovenes (renamed the Kingdom of Yugoslavia in 1929), Aida (born 1969) grew up in the Socialist Federal Republic of Yugoslavia, or SFRY. Darko (born 1989) spent only the first three years of his life in SFRY before he and his family had to flee. When he returned to Mostar at the end of the war, it was to a country called Bosnia and Herzegovina (Figs. 1.1 and 1.2). The lives of Danica, Aida and Darko were all significantly affected by the war that was fought in present-day Bosnia and Herzegovina (Bosna i Hercegovina, $\mathrm{BiH}$ ) between 1992 and 1995, yet they attribute different meanings to that war.

I met Danica, a graceful and cheerful woman of 80 years, at Otvoreno srce (Open Heart), a day-centre for elderly people-a place open to all nationalities ${ }^{1}$ and one of my main research sites. Danica likes to sing

\footnotetext{
${ }^{1}$ Throughout this book, I refer to 'nation' or 'national identity' instead of 'ethnicity' or 'ethnic identity'. In $\mathrm{BiH}$ people employ the terms narod/nacija (people/nation) to describe group identities (Bringa 1995). Moreover, the term 'ethnic' has often been used in a selective and hierarchical way and has been ascribed only to some groups and not to others (Baumann 1996).
}

(C) The Editor(s) (if applicable) and The Author(s) 2016

M. Palmberger, How Generations Remember,

DOI 10.1057/978-1-137-45063-0_1 
traditional Sevdalinka ${ }^{2}$ and delve into her memories of past times, which centre mostly on Mostar's former beauty and the deceased Yugoslav stateman Josip Broz Tito, who she will never stop admiring. Danica does not accept national identities as primordial. Regardless of her Catholic background, she never introduced herself as a Croat to me, as is common in post-war Mostar. ${ }^{3}$ Her best friend, also a regular visitor to Otvoreno srce, is a Muslim. They both first and foremost identify themselves as city dwellers and not in national terms, as Croat or Bosniak, respectively. ${ }^{4}$ In Danica's narrative, World War II (WWII) is of more significance than the 1992-1995 war. When she talks about the latter, she draws on interpretative templates based on her early experience of WWII. Thereby she integrates the 1992-1995 war into a wider narrative of suffering and the fight against fascism. Moreover, her experience of post-WWII reconstruction and economic progress, and the renewed peaceful coexistence of Bosniaks, Croats and Serbs give her hope that times will also get better after the recent war.

The 1992-1995 war was the first war Aida experienced. In contrast to Danica, Aida grew up under relative political and economic stability, and to the day it eventually broke out, a war in her home country was impossible to imagine for her. For Aida, the war in the 1990s constitutes a significant rupture and is connected with the loss of home and future prospects - life is sharply divided into a time 'before' and 'after' the war and the break-up of Yugoslavia. Aida was just about to pursue her career and to establish her own household when war broke out. She had to flee her hometown of Mostar. Now, two decades after the war ended, she still lives with her parents, a fact she connects to the uncertainties the war brought her and her family. She shares with Danica warm memories of Tito (partly transmitted to her by her much-loved grandmother). But she does not share Danica's optimistic outlook that social relations in Mostar will normalise. Aida and I met on a regular basis over a period of three years, mostly in a café or for a walk, but always on the Bosniakdominated east side of Mostar. Only once could I convince Aida to cross

\footnotetext{
${ }^{2}$ Sevdalinka is a traditional folk music from $\mathrm{BiH}$ with very emotional melodies.

${ }^{3}$ In this book Bosnian Croats are referred to as Croats, as is common practice in Mostar, regardless of whether they are in possession of the Croat passport or not.

4'Bosniak' is today the official term for a Bosnian Muslim (Donia 2000).
} 
sides with me to visit Mostar's only proper park. It was the first time since the war that Aida had been to this park, as she no longer feels at home on the Croat-dominated west side, regardless of the fact that she was born and grew up there.

In contrast to Aida, Darko, who was a child when the war in Mostar started, narrates his life as relatively unaffected by the experience of war and its aftermath by distancing his personal experience from that of the wider society. His life narrative is not divided by the war as is Aida's. Darko is a student at Stara gimnazija, Mostar's prestigious secondary school, where Bosniak and Croat students are now taught separate curricula albeit under the same roof. While he is critical of the students' separation, he still has, at least to a certain degree, incorporated the division of Mostar's citizens into separate nationalities (with separate histories) as 'natural'. Whenever I spent time with Darko, wandering around town, meeting for coffee or a movie, he preferred to steer clear of topics concerning war and post-war issues. This was also the case when I asked him for a memory-guided tour through Mostar with a group of visiting foreign students. The places and stories Darko chose to share were strikingly detached from the war's legacy.

Danica, Aida and Darko each belong to one of the three generations identified in this book: Danica to the 'First Yugoslavs', Aida to the 'Last Yugoslavs' and Darko to the 'Post-Yugoslavs'. 5 They position themselves differently in relation to the significant political, societal and economic changes $\mathrm{BiH}$ has faced in the recent past. In this book I introduce the concept of 'generational positioning', which incorporates age as well as stage of life (past and present). I show the way in which generational positioning is significant in how individuals in present-day Mostar narrate their lives, rethink the past and (re-)envision the future, and at the same time (re-)position themselves in post-war and post-socialist society.

Mostar is a city where the rapid political shifts $\mathrm{BiH}$ experienced in the 20th century have revealed themselves most prominently, and it is a suitable place to explore questions related to generation and memory. Mostar has seen severe political and societal transformations over the last century, which culminated in the fall of socialist Yugoslavia and in a brutal

\footnotetext{
5I named the three generations 'First Yugoslavs', 'Last Yugoslavs' and 'Post-Yugoslavs', because their personal experience of different phases of Yugoslavia or the lack of it is decisive in the way Mostarians position themselves in the past.
} 


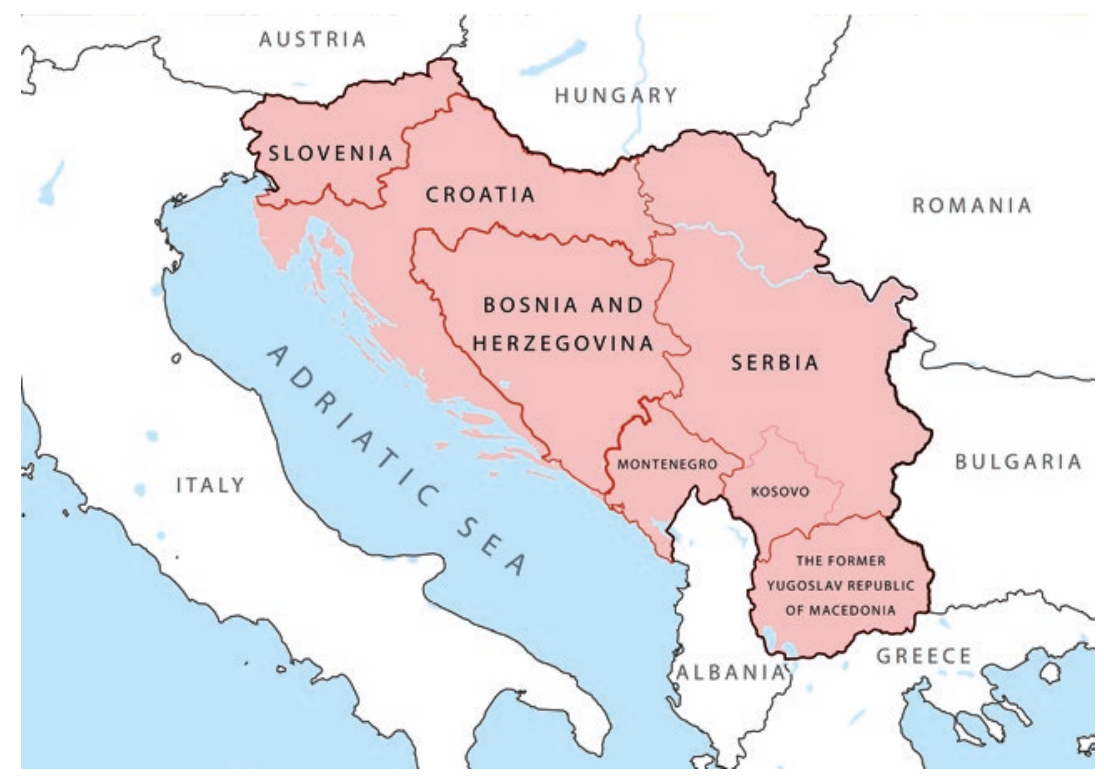

Map 1.1 Map showing the borders of former Yugoslavia, the Federal Republic of Yugoslavia. Map by Alexei Matveev. Map data (- OpenStreetMap contributors

war that divided the once multinational city into a Bosniak-dominated east side and a Croat-dominated west side. Accordingly, experiences of different (often opposing) nationality and memory politics, as well as of different forms of coexistence vary greatly along generational lines. What makes the Mostar case so special is that there has been very limited interaction between Bosniaks and Croats since the 1992-1995 war, and generational commonalities still prevail in the way Mostarians ${ }^{6}$ position themselves vis-à-vis the fractures and turning points of local history. By conducting long-term fieldwork on both sides_-in Bosniak-dominated East Mostar as well as in Croat-dominated West Mostar-and by concentrating on the ways in which individuals give meaning to their personal and their community's past, I reveal generational commonalities that transcend the national border, always so dominant in present-day Mostar.

\footnotetext{
${ }^{6}$ When referring to 'Mostarians' in this book, I mean all people presently living in Mostar, including those who were born in other places.
} 


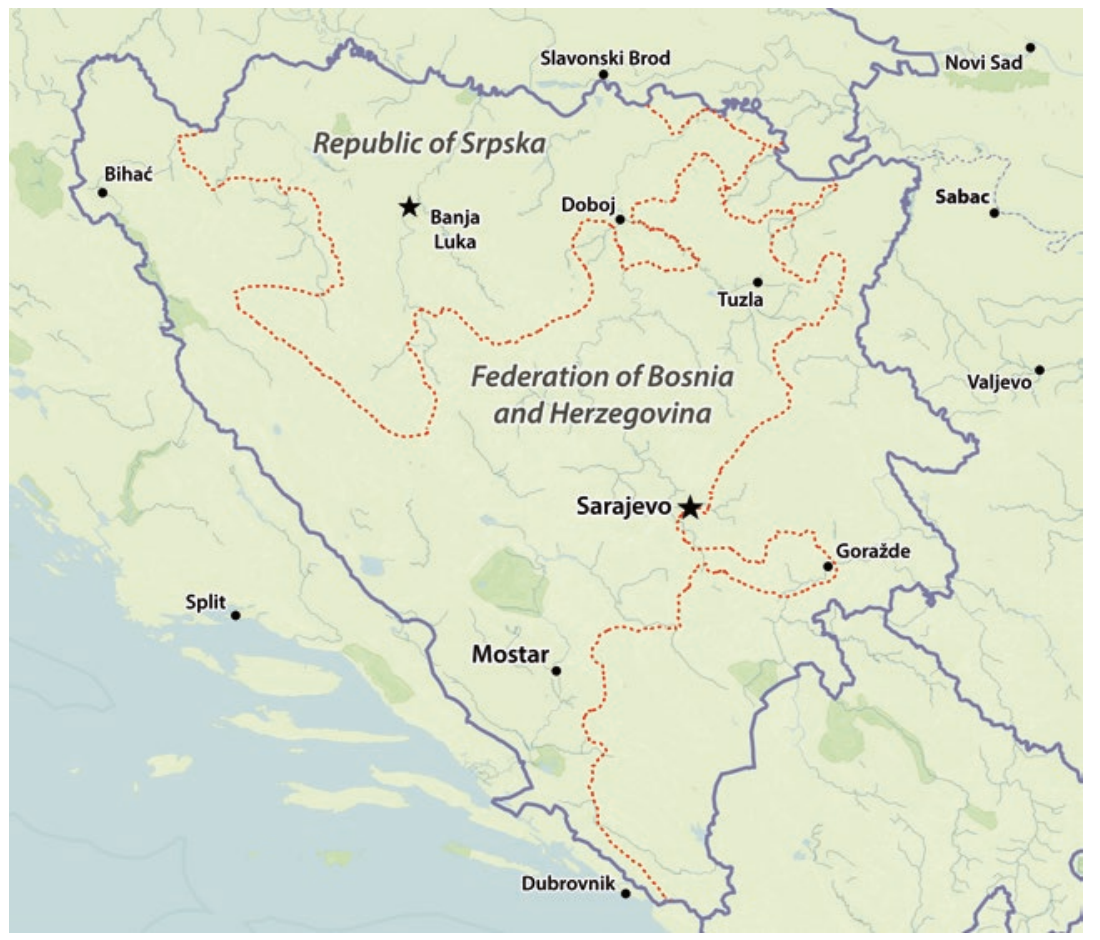

Map 1.2 Map of present-day Bosnia and Herzegovina showing the Serb Republic (Republika Srpska) and the Bosniak-dominated Bosniak-Croat Federation. Map by Alexei Matveev. Map data ( $)$ OpenStreetMap contributors

This book explores how Mostar's different generations place themselves vis-à-vis competing authoritative narratives of the local past. It analyses how experiences and exposure to different political-historical periods/ events and memory politics affect people's historical understanding. I do not suggest that individuals are unaffected by existing canonical national historiographies when orienting themselves anew in society and that they do not take part in reaffirming them. Instead, I argue that we should not assume individuals naïvely take on new dominant public discourses and simply overwrite their previous experiences. Although political changes may come about abruptly and radically, it would be inaccurate to assume that a society fully adapts to all of these changes, and even more inaccurate to imagine that such societal changes take place at the same speed at which political elites change. 
Following Holland and Lave (2001), I view the notion of generation as closely interlinked with memory and history: 'Because history is made in person, registered in intimate identities as well as in institutions, there is every reason to expect that age cuts across people's experiences and creates intergenerational differences' (Holland and Lave 2001: 17). Norman Ryder (1965), another scholar who has vividly engaged in the discussion on generations, has pointed out that traumatic events, such as wars and economic crises, are likely to leave an imprint on the lives of individuals regardless of their stage in life. This is also confirmed in this book. Still, there are significant generational differences in the ways Mostarians make sense of and position themselves towards the past in the present.

This said, the results of my study do not suggest that nationality has become secondary in the lives of Mostarians or that they feel more attached to people of the same generation than to those of the same nation. This is because the three generations identified in the study do not each constitute a community in the sense of being a group based on social interaction. By exploring generational differences in positioning oneself towards the past, I do not by any means attempt to downplay differences between Bosniaks and Croats concerning the respective nationalised historiographies. Nor do I deny other social locations. Besides generational and national identity, other identities, as for example those based on gender, socio-economic or rural/urban background, also play a role when Mostarians position themselves visà-vis the local past (see Altinary and Pető 2015; Helms 2010; Henig 2012; Jansen 2005; Kolind 2008; Leydesdorff et al. 1996; Paletschek and Schraut 2008). Although not at the centre of my analysis, whenever possible these social locations are considered.

\section{Generations: Between Personal and Collective Memories}

In recent decades there has been a strong increase in studies of memory in the social sciences (Berliner 2005). Even if this development has brought a great wealth of insightful studies, one binary set of distinctions 
has remained: the division between personal and collective memory (see Bloch 2007). The division of personal and collective memory often coincides with the division of firsthand and secondhand experiences. Pickering and Keightley make a plea for a closer investigation of 'the way that we take up and synthesise firsthand and secondhand experience in developing self-narratives, how collective "frames" of memory are adopted and applied in everyday remembering processes, and how we make sense of and operationalise institutionalised and objectivised memory' (Pickering and Keightley 2013: 119). By focusing on personal memories as well as transmitted memories and on the specific generational discursive tactics and interpretative templates, this book hopes to contribute towards this aim and to bridge the division between personal and collective memory, even if it can never be eliminated fully. Individuals' narratives are never solely personal memories but are always related to a wider social framework and to the prevailing official histories (Fabian 2007; Halbwachs $1980,1992) .^{7}$ By examining the role of generational positioning, it is precisely the intersection of the individual and the wider social arena that takes centre stage.

In the case of my particular study, I suggest that it is more accurate to speak of a Bosniak or Croat 'dominant public discourse' rather than of Bosniak or Croat 'collective memory' as such. I do so to emphasise that there is a difference between public/official history and what we may call vernacular/popular history, or between those who are professionally involved in creating national history and those who are not. Moreover, by speaking of discourse, we are reminded that the subject of discussion is historically embedded and is thus dynamic, while the notion of collective memory is rather tangible and static.

The title of this book, How Generations Remember, is an allusion to the title of Paul Connerton's seminal book, How Societies Remember (1989). In his book, Connerton opens up a timely discussion going beyond the textual and discursive understanding of remembering by concentrating on embodied/habitual memory and ritual aspects of

\footnotetext{
${ }^{7}$ This central insight serves as the broadest common ground for social scientists working on memory today. Nevertheless, their foci may vary greatly between individualist and collectivist understandings of social (collective) memory (see Olick 1999; Olick and Robbins 1998).
} 
memory. In terms of the study of generations he thus mainly discusses generations as transmitters or receivers of group memory. Although Connerton's pioneering contribution to the study of memory is unquestioned, by focusing on how memory is passed down through the generations he primarily answers the question of how group memory is conveyed and sustained. This emphasis on transmission and persistence leaves open the question of where to locate the individual, the agent, the force and possibility for reflexivity and change (Argenti and Schramm 2010; Shaw 2010). My study, in concentrating on the role of generational positioning, reveals that past experiences inform present stances, but also shows that it is the actor in the present that gives meaning to the past. This is also true for narratives of the past that are passed on from older to younger generations, and are then scrutinised and contextualised by the latter. It is suggested that people's sense of continuity can deal with the inconsistencies that arise with this transfer between generations. It is this field of tension between collective and personal, and between persistence and change that is central in the discussion of generational positioning in this book.

Generations can be seen as 'mediators' between individual and collective memory. Several scholars have proven the significance of family narratives for the process of transmission of memories through generations (see, e.g., Erll 2011a; Feuchtwang 2005; Halbwachs 1925; Hirsch 2008; Welzer et al. 2005). In recent discussions of families as small-scale mnemonic communities, the concept of transmission is critically reflected and sometimes replaced by other concepts, such as 're-narration' (Welzer 2010). Welzer argues that 'narrations of memory are never transmitted, but rather constitute an occasion for an endless line of re-narrations that are constantly reformatted according to generational needs and frames of interpretation' (Welzer 2010: 16). This indicates that generations borrow, cross-reference and negotiate personal and shared pasts in finding their narrative, as suggested by Rothberg's multidirectional understanding of memory (Rothberg 2009: 3). This process of 'bringing into relation different inherited pasts, and use them in orienting ourselves to the future' (Pickering and Keightley 2013: 121) is still 
widely unexplored and the analysis presented in this book hopes to contribute to its elucidation.

Following Mannheim's seminal essay The Problems of Generations (1997 [1928]), most studies linking generation with memory have concentrated principally on the different historico-political periods that individuals of different generations have lived through (see, e.g., Borneman 1992; Bude 2005; Corning 2010; Fietze 2009; Rosenthal and Gather 1986; Schuman and Corning 2012; Schuman and Scott 1989; Yurchak 2005). Some of these studies also consider the stage of life individuals were in when they witnessed a certain event. Adolescence and young adulthood here carry particular weight, and experiences during that early period are seen as formative, as in Mannheim's work. This research does not, however, suggest that such interpretations and norms remain unchanged throughout a lifetime, but only that they continue to be important reference points.

The concept of 'generational positioning' that I introduce in this book gives further importance to the stage of life in the sense of a particular 'life situation' individuals are in at the time when they reflect on the past (and not only at the time of the original experience). For example, we can expect differences in experiences of war between those who live through it as children and those who do so as adults or parents. Still, it is the actor in the present that gives meaning to the past. Thus the narrators' present life situation is likely to affect their retrospective narrations of past events. Consequently, the experience of certain events alone, such as the war, does not signify a generation, rather the interpretative act of making sense of it, whereby individuals position themselves by following certain discursive tactics does. Generational identity is constructed by sharing memories but also by collectively silencing them. Generations assign their identity and at the same time differentiate themselves from other generations.

Due to their divergent life situations, the First Yugoslavs, Last Yugoslavs and Post-Yugoslavs face distinct everyday realities and challenges, and thus are differently affected by the recent societal and economic changes; this influences the way they probe the past. Generational positioning is closely interlinked with the meaning-making and mnemonic processes that are likely to change with the different life situa- 
tions people face (Reulecke 2010: 121) ${ }^{8}$ Giving meaning to past events is a situational process and not a single act. It is likely that the meaning people give to important events and periods in their biography changes during the course of life. Here it is important to state, as Gardner has, that 'the life course is of course not culturally neutral, nor is it unaffected by particular geographical locations, for these involve very real material conditions and power relations' (Gardner 2002: 221). In this book, the power relations concerning the transmission of memories (or the failure of the same) between generations in particular are carved out.

The generations I refer to evolved from my interlocutors' narratives. These generations are understood as sharing a historical experience that generates a 'community of perception' (Olick 1999: 339). A shared past is crucial for a generation's constitution. Equally important are 'certain interpretative principles' and 'discursive practices' (Nugin 2010: 355-356). The narrator takes a central role; individuals are not passive consumers of experiences, but rather play an active role in generating meaning from their experiences.

Even if in most cases the generations outlined here correlate with the age of my interlocutors, we need to keep in mind that the boundaries drawn between the generations are not clear-cut and age alone is not always decisive. Consequently the generations should not be considered as homogeneous cohorts, but rather as trends based on generational identification. The notion of 'generation' used in this book should thus be understood as a heuristic device (see Borneman 1992). Regardless of shared 'discursive tactics' identified, I did not encounter one 'standard' narrative representative for each generation,

\footnotetext{
${ }^{8}$ There is widespread interest today in the concept of generation within the social sciences and beyond. Yet it is understood in many different ways, not only between but also within disciplines. Existing research spans studies on kinship and family (see, e.g., Bertaux and Thompson 1993; Lisón Tolosana 1966; Parkin and Stone 2004), to ageing and the intergenerational contract (see, e.g., Lüscher and Liegle 2003) and life-course research related to political attitudes and educational and career paths (see, e.g., Mayer 2009). In the last few decades, generation has become a central concept in research on migration, connected to studies on exiles (see, e.g., Ballinger 2003; Berg 2009) as well as second-generation migrants (see, e.g., Vertovec and Rogers 1998; Wessendorf 2007). Moreover, generation has also been a topic in life-course and biography research connected with political ruptures (see, e.g., Borneman 1992; Diewald et al. 2006; Rosenthal and Bogner 2009) as well as in studies concerned with intergenerational aspects of memory (see, e.g., Argenti and Schramm 2010; Bloch 1998; Hirsch 2008; Welzer 2007).
} 
and even narratives told to me by the same person sometimes varied significantly depending on the situation in which they were told.

Lastly, the generations here are not political generations who share a politico-ideological outlook (see Bude 1997). The First, Last and PostYugoslavs are not necessarily connected through their political outlooks; what they share are certain discursive tactics in the ways they (re-)positioned themselves after the war. In this sense each generation may be seen as a group of people who share a certain processing of experiences, as suggested by Lüscher (2005) in the phrase 'gemeinsame Verarbeitung von Erfahrungen' (a shared way in coming to terms with the past) (Lüscher 2005: 55). This is especially interesting if one considers that the contact between the Bosniak and Croat members of the generations is extremely limited. For the Post-Yugoslavs this has been true for most of their lives, yet this is the group that most often refers to itself as one generation, thereby differentiating themselves from the older population. As I show in Chap. 6, they do so not only by means of sharing memories but also by silencing them.

\section{A Narrative Approach to Remembering}

In this study, I concentrate on what Assmann and Czaplicka (1995) refer to as 'communicative memory'. This is the memory that is still preserved among living generations, and this time span is most important for individuals' perception of their lives. The aspect of time is crucial here because communicative memory is limited to a time span of around 80-100 years (during which eyewitnesses to the events remain alive) (see Assmann and Czaplicka 1995). Central political periods (rather than specific events) - and the meanings they assume in the life narratives of individuals of different generations-are central in my analysis. The three historico-political periods primarily explored in this book thus are the period of socialist Yugoslavia (including the constituting period of WWII), the war in the 1990s and the post-war period. These are tightly interconnected and often narrated in relation to each other, both in public history representations as well as in personal accounts. 
The entry point I have chosen for this research are narratives of different forms (and in different settings) that allow me to make visible the actors and their strategies/tactics for dealing with the past. Memories are thus understood as interpretations of the past that always include intellectual work (Wood 1991). Narratives are simultaneously born out of experiences and structure experience (Ochs and Capps 1996). In contrast to the cognitive approach to memory, in which memory is only attributed to the individual mind, the narrative approach taken here treats memory as a social practice because it is communicative (Fabian 2007).

Whenever the notion of memory is used in this book, it should be understood as a narrative that is selective and situational in character, and a product of past experiences, present needs and future aspirations. Although at first glance memory might seem to be chiefly connected to the past, it is also closely linked to the present and the future (Haukanes and Trnka 2013). We remember in order to give meaning to the present and thus gain power over the future (see Assmann 2007; Schwartz 1982). Thus we are confronted with different temporal moments including the inherited and experienced past, the present moment of narration as well as the imagined future (Pickering and Keightley 2013: 125; see also French 2012). Consequently, narratives of experienced events refer both to current life and to past experience but are also linked to what the future holds for individuals as well as for societies (Kerby 1991; Koselleck 2004; Natzmer 2002; Palmberger and Tošić 2016; Polkinghorne 1998).

As Trouillot (1995) has rightly stated, 'human beings participate in history both as actors and narrators' (Trouillot 1995: 2). This means that individuals are narrators of history and also actors, and thus are not entirely free to choose since their narratives of the past are based to a certain degree on personal experiences and on wider public narratives they have been exposed to. This becomes apparent in the discussion of generations I present below. Despite all the choices individuals can draw on when narrating the past, they are also influenced by experiences in the past and by socio-historical structures (Rosenthal 2006: 1). Memories are thus selective constructions incorporating experience (Kansteiner 2002).

Processes of remembering not only enable us to make sense of our pasts, but they also help in identity constructions. 
Memory serves as both a phenomenological ground of identity (as when we know implicitly who we are and the circumstances that have made us so) and the means for explicit identity construction (as when we search our memories in order to understand ourselves or when we offer particular stories about ourselves in order to make a certain kind of impression). (Antze and Lambek 1996a: xvi) ${ }^{9}$

To be precise, it is not only a matter of the way the past is narrated, but also of the way the narrators position themselves in the past (Antze and Lambek 1996b). The way that meaning is attributed to past experiences is likely to change during one's lifetime due to changes in historicopolitical contexts, new autobiographical experiences and the fact that one is moving forwards in the life cycle (Rosenthal 2006). The dimension of temporal transformation and new interpretations of the past in new presents has generally been little explored and calls for closer investigation, not least through the focus on generation (Feindt et al. 2014).

\section{Different Temporal Moments in the Process of Remembering}

As the preceding paragraphs have illuminated, the work presented here builds on the premise that memory (or better 'remembering') is an active process. Remembering is understood as a narrative act of generating meaning located in the present and directed towards the future. Remembering is 'not only welcoming, receiving an image of the past, it is also searching for it, "doing" something' (Ricoeur 2006: 56; see also Hodgkin and Radstone 2006; Passerini 2007; Schwartz 1982; Tonkin 1992).

Remembering and its counterpart, forgetting/silencing, therefore have little to do with a mere retrospection on the past (Fabian 2007; Rasmussen 2002), but also relate to the way one's present and future are conceptualised (Ochs and Capps 2001: 255; see also Erll 2011b; Lowenthal 1985; Tannock 1995). Memory thus acts as an orienting force and 'there are times when a very specific vision of the future frames the utilization of the past' (Irwin-Zarecka 1994: 101). As I show at different points in this

\footnotetext{
${ }^{9}$ On this matter see also Cole and Knowles 2001; Friedman 1992; Jureit 2009.
} 
book, nostalgia for Yugoslavia manifested within the three generations' narratives and as such is a representation of the past that at times serves as a vision for the future.

Nostalgic feelings for the socialist past have been identified in many post-socialist contexts, and nostalgic icons have been identified as 'mnemonic bridges' between the present and the past that offer continuity in times of wide-reaching societal changes (Ange and Berliner 2015; Bach 2002; Bartmanski 2011; Boym 2001; Brunnbauer and Troebst 2007; Creed 2006; Heady and Gambold Miller 2006; Velikonja 2009; Yurchak 2005). As recent work on post-socialism has shown, it would be wrong to assume 'a clear break from the past' and from experiences of socialism eradicated from people's memories (Kay et al. 2012; see also Greenberg 2014; Pine 2013; Ringel 2013). Assuming that regime changes coupled with war are likely to intensify feelings of loss and insecurity, and trigger a yearning for the past, it is not surprising that a longing for the pre-war times, for Yugoslavia, prevails in $\mathrm{BiH}$. People in $\mathrm{BiH}$ have experienced not only a drastic change in the political system governing their country, but also the war that accompanied it.

This book builds on the past-present-future interrelations inherent to nostalgia (Davis 1977). Rather than viewing nostalgia for Yugoslavia as oriented towards the past alone, I argue that it can also be seen as criticism of the present post-war and post-socialist realities, and may be reflected in visions of a better future (see Boyer 2006). It is suggested that a longing for Yugoslavia has the potential to 'paralyse' individuals, who realise that what was lost can never be regained, and this puts them into a constant state of 'waiting'. At the same time this longing is an expression of criticism of the present situation and in this way can become a source for future aspirations. As I reveal in this book, nostalgia shows itself in different forms along generational demarcations.

\section{Between Memory Politics and Individual Meaning-Making}

In his critical article on memory studies, Confino (1997) argues that the discussions of memory in recent decades have reduced memory to 
the political. In a similar vein, Kidron (2009) expresses concern about the vast scholarly interest in the political instrumentalisation of the past while neglecting the more silent everyday mnemonic practices that constitute the 'living presence of the past' (Kidron 2009: 8). I would argue that this is particularly true for the case of Yugoslavia, noticeably in the concentration of literature on nationalism and memory politics. The frequent succession of political regimes in the region of former Yugoslavia and their continuing efforts to rewrite local history have inclined social scientists to approach the region as a 'laboratory' for studying memory politics, whereby the ethno-national groups serve as the focus of analysis. The majority of research on Yugoslavia and her successor states concerning itself with memories and representations of the past thus has focused on partisan collective memory among the different ethno-national groups. This research has explored how the new political elites, after crucial political changes, rewrite the past in order to legitimise their rule and to make the past fit nationally oriented goals (see e.g., Basic-Hrvatin 1996; Bet-El 2002; Denich 1994; Hayden 1994; Moll 2013; Verdery 1999). These studies are of great value. Nevertheless, the focus on collective memory is often maintained at the expense of the individual agent. It bears the risk of obscuring the view on diversity, such as other identities existing alongside only national ones. ${ }^{10}$

Recent work on public representations of the Yugoslav past has added to the already existing literature new angles of analysis going beyond the national fractions. Helms (2013), for example, in her work skilfully analyses the way Bosnian national narratives greatly rely on gender logics. While female victims of sexual violence and rape are faced with silence and have received little support, they, as a collective, have become symbols and proof of the nations' innocence (Helms 2013). Such gendered discourses of victimhood are followed, primarily, to prove the nation's moral purity and are instrumentalised to attract international aid projects. Another example of recent work on political/national memory in the post-Yugoslav successor states is that of Gordy's work, which in a dif-

\footnotetext{
${ }^{10}$ This shift away from the traditional focus on ethnicity in research and analysis has also been initiated by leading scholars in other social science research fields, such as in the field of migration studies (see Glick Schiller et al. 2006; Vertovec 2007, 2014).
} 
ferentiated way and based on rich ethnography investigates memory and responsibility in present-day Serbia (Gordy 2013).

Compared to the attention that public, national discourses have received, however, little research has been conducted on local-level responses, on the way 'ordinary' people deal with disruptions and war, and how they reflect upon their lives and consider the significant political ruptures that have taken place during their lifetimes. Most importantly, what has been widely left unexplored is the interplay between personal memories and memory politics, a gap this book aims to fill. Together with other recently conducted research in the Yugoslav successor states (e.g., Brown 2003; Höpken 2007; Jansen 2002; Kolind 2008; Schäuble 2014; Sorabji 2006; Volcic 2007), this book hopes to provide a necessary corrective to this distorted picture, not by ignoring the dominant national public discourses (drawing on so-called 'collective memories'), but by considering them as powerful foils against whose backdrop people's narratives are constructed. Thereby, the difference between the nature of the 'stratagems' found in the dominant public discourse (Bosniak and Croat) and in people's personal narratives is investigated.

\section{Discursive Tactics versus Discursive Strategies}

In order to tease out the particularities of my interlocutors' narratives and the discursive tactics they employ (Chaps. 4-6), I first introduce the key themes found in the dominant Bosniak and Croat public discourses (Chaps. 2 and 3). Mainly using material gathered in the history departments of the Bosniak- and Croat-dominated universities in Mostar, but also at commemoration ceremonies, I analyse how history has been rewritten since the end of socialist Yugoslavia. In this process I point out specific discursive strategies employed in the historical narratives of the university lectures and those officiating at the ceremonies. My research reveals that there is a difference between the nature of the 'stratagems' found in the official (Bosniak and Croat) national narratives and in people's personal narratives. By way of clarification, I use 'discursive strategies' to refer to what is employed by those professionally involved in the process of (re) writing history (the political elites and their intermediaries; e.g., historians, 
teachers, journalists) and 'discursive tactics' to refer to what is employed by those who are not.

Since individuals are not only exposed to changing political contexts but are also confronted with their personal past experiences, my interlocutors' reconstructions of the past have to remain more flexible and situational than those of 'memory makers' (Kansteiner 2002) who are professionally involved in writing official national history. While the latter presents a goal-oriented narrative, the former can be better described as target-seeking. This usage relates but does not fully correspond to Michel de Certeau's distinction between strategy and tactic. ${ }^{11}$ For de Certeau, the former is linked to institutions and structures of power: 'I call a strategy the calculation (or manipulation) of power relationships that becomes possible as soon as a subject with will and power (a business, an army, a city, a scientific institution) can be isolated' (de Certeau 1984: 35-36). Discursive strategies employed by those who claim to represent the nation are used to narrate independent coherent national histories, to legitimise and objectify them.

In contrast to discursive strategies, discursive tactics are found in the narratives of 'common' citizens who are not professionally involved in rewriting the past but who nonetheless are faced with having to rethink it and to reposition themselves with reference to it after great societal changes have taken place in their country. A tactic, in de Certeau's sense, is utilised by individuals to create space for themselves in a field of power. A tactic is influenced, but not determined, by rules and structures (de Certeau 1980). In positioning themselves in relation to the past, Mostarians are confronted with the political ruptures in their society's history. Discursive tactics present in their narratives are utilised to deal with these ruptures. ${ }^{12}$

In my work, discursive tactics are first and foremost verbal expressions by actors in the field that position an actor in relation to the local past, primarily to the period of Tito's Yugoslavia (including WWII), the war in the 1990s and the post-war period. While a central discursive tactic employed by the First Yugoslavs is the connecting of experiences of dif-

\footnotetext{
${ }^{11}$ The idea of making use of this distinction came from a stimulating conversation with my colleague and friend, Kristine Krause.

${ }^{12}$ Even if individuals may strive towards a meaningful life narrative, I nevertheless recognise that it is also the researcher's aim to reveal a meaningful story (Bourdieu 1998: 76).
} 
ferent historico-political periods, that of the Last Yugoslavs is the oscillation between different discourses, even opposing ones; and the discursive tactics of the Post-Yugoslavs are characterised by distancing and dissociating their personal histories from the experiences of the wider nation.

Although the concept of discursive tactic used in this study relates to de Certeau's concept of tactic, it is understood in a somewhat different way. Tactic as de Certeau describes it is more closely linked to resistance than the way tactic is used here. Relating tactics closely to resistance would suggest that the narratives of my interlocutors represent 'counter-memories' or 'alternative histories', and that we can draw a clear line between 'official' and 'popular' representations of the past, between history and memory. This is not the case, as I will outline in the following paragraphs.

\section{The Fine Line Between Memory and History}

I suggest being critical of drawing a clear line between memory and history and instead emphasise their interrelationship. Connerton claims that 'the practice of historical reconstruction can in important ways receive a guiding impetus from, and can in turn give significant shape to, the memories of social groups (Connerton 1989: 14). Hutton argues in a more radical way that historiography cannot be seen as a process freed from memory, but rather as an official version of memory which enjoys the sanction of academic authority (Hutton 1993; see also Assmann 1999; Crane 1997; Hall 1998). This does not mean that memory and history are synonymous, but rather that 'memory is history located in relatively subjective space; history is memory located in relatively objectified space. History is memory inscribed, codified, authorized; memory is history embodied, imagined, enacted, enlivened' (Lambek 2003: 212). Lambek's portrayal of memory and history is useful as a working definition here, since it shows both the interconnectedness of memory and history, as well as their different qualities. Despite their differences, the connection between history and memory is reinforced by the fact that they are both mnemonic processes (see Burke 1989) and that they influence each other to a certain degree. 
On the individual level, too, history is not always clearly separable from autobiographical memories. 'Unlike law and policy texts, personal recollections rarely attempt to divide history into discrete categories of political and domestic life, into a set of objective circumstances and subjective responses' (Borneman 1992: 38). As shown in this book, individuals make sense of the past by referring to autobiographical memories as well as to secondhand pasts (e.g., narratives of older family members) and institutionalised/official histories, which are intermingled in their narratives. The creation of a 'generational consciousness' is 'creatively produced not by making a complete break with inherited pasts, but through the dialectical relationships between continuity and rupture, intimate knowing and irreducible difference that occur vertically through time in genealogical relationships' (Pickering and Keightley 2013: 126).

On the national level, representations of the past are struggles over whose memories will be preserved and institutionalised and whose will be repressed or forgotten (Natzmer 2002; see also Purdeková 2008; Vidaković 1989). Memories first have to be included in a widely shared and publicly expressed narrative before they can have political effect (Ashplant et al. 2009). Because different groups in any society have unequal access to power, the starting positions for making one's own perception of the past representative in the public domain are unequal. ${ }^{13}$ The state holds a privileged position in terms of historiography whereby the discourse of the state is presented as knowledge (history) while that of its citizens is presented as opinion (memory) (Borneman 1992: 40). This does not mean, however, that official historiographies are not contested, as Tilly (1994) reminds us when he says:

At least two processes within the politics of memory can be identified: On a large scale we see the whole political process of mutual influence among shared memories, definitions of the future, and collective action. At an increased magnification, we see the contestation that surrounds every effort to create, define, or impose a common memory. [...] (Tilly 1994: 253)

\footnotetext{
${ }^{13}$ In order to uphold a dominant discourse that supports existing power structures, ruling politicians take advantage of commemorations and (war) memorials as well as of the reburials of the dead (see Bougarel 2007; Campbell et al. 2000; Sant Cassia 2005; Verdery 1999).
} 
Counter-versions may emerge at the same time as a dominant narrative is told or after years of silence (see Foucault 1977; Gal 2002; Ochs and Capps 1996; Saikia 2004). Within an authoritarian state, such narratives are likely to remain in the private sphere or outside of state control (e.g., in the memories of dissidents). In this context it is tempting to view the dominant discourse as oppressive and negative, and the discourses that contest it as positive and closer to 'truth'. However, rather than asking about the truth of the official or counter-narratives, the more relevant and significant question, also for this book, is about the relationship between them (see Fentress and Wickham 1992). They are necessarily interrelated, since any counter-narrative always relates to the dominant discourse (see Schramm 2011). Moreover, as will become clear in Chaps. 2 and 3, which deal with the memory politics and historiography of the Yugoslav period and in the present, the status of narratives is not fixed: a counter-narrative can become the dominant narrative manifested in historiography and vice versa. Nevertheless, even if we no longer treat history and memory as antithetical concepts, it does not mean that no distinction between the two should be made. Instead, I suggest that the question of interconnectedness should be explored within the specific ethnographic context.

By opting to speak of narratives of the past, I seek to avoid drawing too clear a distinction between memory and history. It is not useful to draw a strict line between memory and history, neither analytically nor ethnographically. With regard to the latter, Birth argues:

To ethnographically explore the fluid, interdependent relation between history and memory discards an inflexible bifurcation of the past into 'history' versus 'memory.' This dichotomy plays a role in both the purported objectivity of history and subjectivity of remembering. In this contrast, history becomes contextual, and 'memory,' whether it is collective or individual, becomes a dimension of intersubjective significance. (Birth 2006: 177)

In this book I treat both memory and history firstly as narratives and only later elucidate their different qualities, particularly when drawing on the distinction between discursive strategies and tactics. The arbitrary distinction between memory and history becomes clear when we look at concrete ethnographic examples, such as the way history is taught at 
the two universities in Mostar. Here we are dealing with more than one version of history: it is history in the making but at two different ends.

\section{Situating Mostar's Memories}

Many of the people I talked to were quick to assure me that I had come to the right place when I told them I had come to Mostar to research memories of the local past. Independently of one another, many of them said that in Mostar 'we have too much memory'. This statement refers to the history of the territory (and its inhabitants) that is today the country of $\mathrm{BiH}$, a territory that was contested fiercely throughout history and claimed by various rulers (domestic and foreign) until it became one of the six republics of the Democratic Federal Yugoslavia in $1945 .{ }^{14}$ It was again violently fought over in the years following 1992, when it became the battleground for contesting national claims in the course of Yugoslavia's disintegration. Certainly, the statement 'we have too much memory' is also connected to the widespread perception of the Balkans as a region prone to violence (Todorova 1997). This perception is also found in local history textbooks in which the outbreak of the 1992-1995 war is commonly presented as inevitable due to ancient hostilities among the peoples of Yugoslavia (Torsti 2003).

It seems that such a deterministic perspective on the past could only have evolved in retrospect. The majority of my interlocutors narrated the outbreak of the war as having been abrupt and unexpected. According to those among them old enough to remember pre-war Mostar, the war has disfigured the city almost beyond recognition. In this they refer not only to the severely damaged cityscape and the fully destroyed parts of Mostar (including the Old Town and the famous Ottoman Bridge), but mainly to Mostar's social core: the social relations between the city's inhabitants often framed using the local term komsiluk (neighbourliness) (see Bringa 1995; Henig 2012; Sorabji 2008; see Chap. 3 this volume). Pre-war Mostar, people on many occasions assured me, best exemplified what

\footnotetext{
${ }^{14}$ In 1946 it was renamed the Federal People's Republic of Yugoslavia and in 1963 the Socialist Federal Republic of Yugoslavia.
} 
Bosnia and Herzegovina supposedly stood for: peaceful coexistence among individuals of different national backgrounds. Accordingly, statistics showed Mostar to be the city with the highest number of crossnational marriages in all of Yugoslavia (Botev and Wagner 1993). The destruction of Mostar's Old Ottoman Bridge in 1993 became a symbol of the destruction of this multinational coexistence in $\mathrm{BiH}$, for locals and non-locals alike (Bjelakovic and Strazzari 1999).

The Bosniak and Croat dominant national narratives deviate starkly when it comes to the interpretation of the 1992-1995 war. Although Bosniaks and Croats agree that the Serb-dominated Yugoslav National Army (YNA) presented the primary threat to Mostar, they disagree about the reasons for the war that broke out among them after they had successfully pushed back the YNA. While in the Bosniak national discourse the Bosniak-Croat war is narrated as a matter of Bosniaks liberating Mostar from Croat fascists (like the Partisans' liberation of Mostar from the Nazis at the end of WWII), in the Croat national discourse the Bosniaks are portrayed as traitors who turned against their former protectors in order to Islamise Mostar.

With the Dayton Peace Agreement that ended the war, $\mathrm{BiH}$ became a state with two entities - the Bosniak-Croat Federation with its 10 cantons and the Serb Republic - with a strong presence of international actors (Bieber 2005). The city of Mostar is the capital of one of the only two mixed cantons and traditionally has been the centre of the Herzegovinian Croats (as Sarajevo is the centre for BiH's Bosniaks and Banja Luka for $\mathrm{BiH}$ 's Serbs). For tourists, Mostar, a city in the southern region of $\mathrm{BiH}$, initially impresses with its beauty and Mediterranean charm. Only after gaining deeper insights into the lives of people do the scars left by the war and the way they still dominate life in Mostar today become visible.

One day during the first months of my fieldwork, I ran into a woman in her 40s who had got lost in Mostar, a city that used to be her home. She had had to flee it during the war and only returned for the first time in 2005. Upon her return she became lost in Cernica, the part of the city where I lived with my family, and she had to ask her way around as she could no longer recognise the streets. This incident again made me aware of how the city had changed. The once-colourful Mostar is now full of ruins and damaged facades. The trees growing out of the ruins 
give a sense of the time that has passed since the war ended. The ruins and bullet holes in the buildings, visible throughout the entire city, are much worse on the east side than on the west side because of the Croats' advantage in heavy artillery. The situation is worst around the former frontline, the Bulevar (Bulevard), close to where the returnee lost her bearings. ${ }^{15}$ This anecdote represents an extreme case. It is likely that the woman experienced a lot of stress when returning to her former home for the first time after more than 10 years. But the experience of no longer recognising Mostar or parts of it as one's former home-literally or metonymically_-was described to me by many Mostarians.

The composition of Mostar's population has changed drastically as a consequence of the war. The once multinational city-35\% Muslim (Bosniak), $34 \%$ Croat, $19 \%$ Serb and $12 \%$ Other (including those who identified themselves as Yugoslav)_ _has been split in half between Croats and Bosniaks, who make up the vast majority of the population. Of the approximately 20,000 Serbs, only about 1000 remained in the divided city during the war, and only a minority of those who fled returned thereafter (Bose 2002). Today, Mostar is often cited as the 'worst case' of partition resulting from the war (Bjelakovic and Strazzari 1999).

The war left Mostar as a city divided between a Bosniak east side and a Croat west side. Even after Mostar's inhabitants were again able to move about the city freely, the two sides remained separated in all aspects of life: politically, economically, culturally and also in terms of health care, education and the media (see Bose 2002; ICG 2000; Price 2002; Torsti 2003; Vetters 2007; Wimmen 2004). The lives of most Bosniaks and Croats are still separated. If they do not actively seek to interact with one another, then Bosniaks and Croats actually share little time with their national counterparts. Bosniak and Croat children attend different schools, teenagers go to different universities, adults have separate workplaces, and leisure time is predominantly spent on 'one's own' side of the city. Only a small number of people still maintain friendships with pre-war friends of a different nationality and even for them the nature of their relationships has often changed. Many Mostarians who still maintain old cross-national friendships no longer visit each other at home like they used to do before

\footnotetext{
${ }^{15}$ Fortunately, the Bulevar, which still is 'perceived' as the border between Bosniaks and Croats, saw much reconstruction during the three years of my stay in $\mathrm{BiH}$.
} 
the war, but only meet in public places such as cafés. This change symbolises a shift in the degree of intimacy in these old friendships.

Although no exact numbers exist, my fieldwork observations suggest that only a minority of Mostarians feel at home on both sides of the city. The majority only crosses the line between east and west if there is particular reason for it. For example, young Bosniaks prefer to go shopping in West Mostar because shopping malls are bigger and fancier. Sometimes such shopping expeditions are combined with having a coffee in one of the chic cafés close by. On the other hand, a modern beauty salon opened during my stay in East Mostar, and it attracted Mostar's Croats. Such 'crossings', however, do not mean that people feel at home on the side where they are in the minority (even though some of them grew up there).

For example, a Bosniak woman of around 30 years of age told me that she feels watched in cafés on the west side. She always tries to use Croat instead of Bosnian words and fears accidentally using a turcizam. ${ }^{16}$ Later, when re-crossing the Bulevar to arrive on the Bosniak side, she feels relieved for only then can she relax again. A Bosniak man of similar age told me that he did not feel safe on the west side. This feeling of insecurity had intensified since he went out one night with his friends in West Mostar and lost his mobile phone in a club. The waitress found it, searched for his name and when she called it out in order to identify him a couple of men came up to him and asked him aggressively what he, as a Bosniak, thought he was doing in that club. ${ }^{17}$

Both Bosniaks and Croats expressed a sense of insecurity when on the other side and when identified by people there. On the other hand, I also met people from both sides who did not (or no longer) feel insecure when crossing sides. This was particularly true for those who regularly spent

\footnotetext{
${ }^{16}$ Turcizam means a word of Arabic origin incorporated into what used to be referred to as SerboCroatian and nowadays is used mainly by Bosniaks or the older population.

${ }^{17} \mathrm{Names}$ in $\mathrm{BiH}$ in many cases provide information on a person's national background and are almost always 'screened' for this information. But not every name can be easily categorised, which might confuse the interlocutor, for example, when the first and last names suggest two different nationalities or when a name is common to more than one nation. Individuals with such names may take advantage of this since they can pass for more than one nationality and so may gain more access to resources, such as education or employment. But not being clearly identifiable as a member of one nation can also cause suspicion and serious problems, as was the case especially during the war for mixed couples and their children.
} 
time on the other side, for example those who worked or studied there (Palmberger 2013b). In contrast, those who rarely crossed sides expressed deeper mistrust. In the media and literature one often hears of hatred between Bosniaks, Croats and Serbs in post-war BiH. I encountered such feelings only among a small number of people. For most, what remains between Bosniaks and Croats is a combination of mistrust, a feeling of uneasiness and a desire for conformity rather than outright hatred.

To some degree I also internalised the city's division, always being aware of which side I was on when walking through Mostar. Only when I was showing visiting friends around the city did I realise, from their innocent questions about the side we were on, that there were indeed no clear signs marking the exact border between Bosniak and Croat Mostar. Nevertheless, some markers providing hints of the 'nationality' of the two parts of the city exist. Since religion is the main marker of national identity in $\mathrm{BiH}$, religious symbols are the most straightforward territorial markers. Many mosques and churches have been built in recent times, and they attempt not only to outnumber one another but perhaps also to compete in size. This is not only the case in Mostar but also in its surrounding small villages. This does not necessarily mean, however, that everyone welcomes the massive investment in churches and mosques. Quite to the contrary; many expressed great displeasure at what they regarded as a waste of money, money they thought would have been better invested in public amenities such as schools and hospitals. This was also the case for Armen, an octogenarian, who is introduced in more detail in Chap. 4. While driving from Mostar to Sarajevo with Armen, we passed numerous small villages. As I had just arrived in $\mathrm{BiH}$, I did not know about the national division of the villages and so asked Armen if he could tell me about them; he gave what I believe was the best response by saying: 'Here every cow is either Bosniak or Croat, even the mice have Bosniak or Croat identities!'. With this statement he not only made clear what he thought of fanatical nationalism but also expressed his disapproval of my question. During our journey, I saw him shake his head repeatedly, in disbelief at the investments that had been made in the construction of churches and mosques.

Probably the most striking religious territorial marker in Mostar and a good example of the 'symbolic arming' that also goes on here is a huge 
cross on the summit of Mount Hum, which overlooks the city. The cross is so big that it sticks out of the landscape and is one of the first signs visitors driving into the city see. The installation of this cross greatly provoked the Bosniak population, especially considering the fact that it was from Hum that the HVO (Hrvatsko vijeće obrane, Croat Defence Council) artillery shelled East Mostar. After several years, however, the cross has become, if not accepted, then at least a popular subject for jokes among the Bosniak population. For example, they joke that the cross, if not good for anything else, at least provides much-needed shade during hot summer days.

On another mountain, on the east side of the city, there is a huge sign laid out in white stones stating in capital letters, ' $\mathrm{BiH}$ volimo te' $(\mathrm{BiH}$ we love you). Peculiarly, before the war it read 'Tito volimo te' (Tito we love you) but had to be revised after Tito's death and Yugoslavia's break-up. For everyone who is informed about the situation in $\mathrm{BiH}$, it is clear that such a statement could only be found on the Bosniak-dominated side. Most supporters of the new $\mathrm{BiH}$ state can be found among Bosniaks, while Croats generally show more patriotic sentiments for Croatia than for BiH. Many Croats in Mostar, as in the whole of Herzegovina, orient themselves towards the capital of Croatia rather than Sarajevo, the capital of $\mathrm{BiH}$. On public holidays, in West Mostar the flag of $\mathrm{BiH}$ is only displayed on official governmental buildings and on the buildings of international organisations, while on the east side the $\mathrm{BiH}$ flag can be seen on many buildings, even on small shops.

This orientation towards Croatia is also displayed in the newly renamed streets in West Mostar. While on the Bosniak-dominated east side, street names for the most part remained as they were before 1992, street names on the Croat-dominated west side underwent extensive renaming. Today, street names, newly erected memorials and religious symbols mark the public space of West Mostar as part of the Croat nation (Palmberger 2013c). ${ }^{18}$

\footnotetext{
${ }^{18}$ The claim that Mostar is the city of BiH's Croats leads, in its extreme interpretation, to a denial of Bosniak (and Serb) existence or to a denial of the Bosniak-dominated part of the city. The claim that Mostar is an exclusively Croat city goes so far that the Bosniak east side of the city is simply ignored, for example in books on or maps of Mostar (see, e.g., Augustinović 1999). Interestingly, a study of Mostar's tourist guides conducted by Torsti revealed that Bosniak tourist guides continue to present the entire city similarly to before the war, while Croat guides concentrate only on West Mostar and leave the Ottoman heritage, such as the Old Town, unmentioned (Torsti 2004: 151). When we assume that 'recognising others' means also 'remembering them' (Fabian 2006: 145) then silencing the Bosniak presence is a denial of its existence through the act of wilful forgetting.
} 
The new street names emphasise a shared history with the motherland of Croatia by recalling Croat historic personalities and important Croat cities. The former include names of members of the Catholic Church and politically influential persons from the medieval Croat Kingdom as well as the NDH state (Nezavisna Država Hrvatska, Independent State of Croatia, see Chap. 2). The new street names invoke the national meta-narrative by recalling the past glory of the medieval Croat Kingdom as well as the long period of victimisation on the way to national liberation. The victimisation of the Croat people by the communists is thereby given special attention.

The propagated Croat identity stands in sharp contrast to the Yugoslav identity and the socialist past. To maintain it, any reminders of the Yugoslav past had to be erased from everyday life. This also concerns street names whereby the socialist past was erased by 'Croatianising' them. For example, the street once called Omladinska (Street of the Youth) was renamed Hrvatske mladeži (Croat Youth). A similar example is the cultural centre formally called Dom kulture (House of Culture; Fig. 1.1). Today, big letters on the front of the building proclaim its new name: Hrvatski dom herceg Stjepan Kosača (Croat House-Duke Stjepan Kosač).

In West Mostar, moreover, streets recalling the socialist period and those named after people known for their role in Serb or Bosniak national history were replaced by the names of Croat rulers, such as kings and dukes, or religious leaders, such as cardinals and bishops (Fig. 1.2). They were also renamed in memory of recent national heroes and victims, or after Croat cities in order to emphasise their affiliation with Croatia. For example, a street previously named ulica Jakova Baruha Španca, after a Spanish communist revolutionary, is today called ulica Žrtava komunizma (Victims of Communism Street). This policy of exclusion is supported by publicly remembering (within commemorations and through memorials) only the victims belonging to one's own nation. In Mostar, new memorials and commemorations are dedicated to victims of either Bosniaks or Croats. Any ceremony commemorating atrocities committed during the war in the 1990s in Mostar is sure to draw plenty of media attention. Even if the number of direct participants is small, the evening news and local newspapers ensure that a good part of the population does not 'forget'. However, even in those places where the dominant discourses are so obviously prescribed, we cannot simply assume that these memorials and 


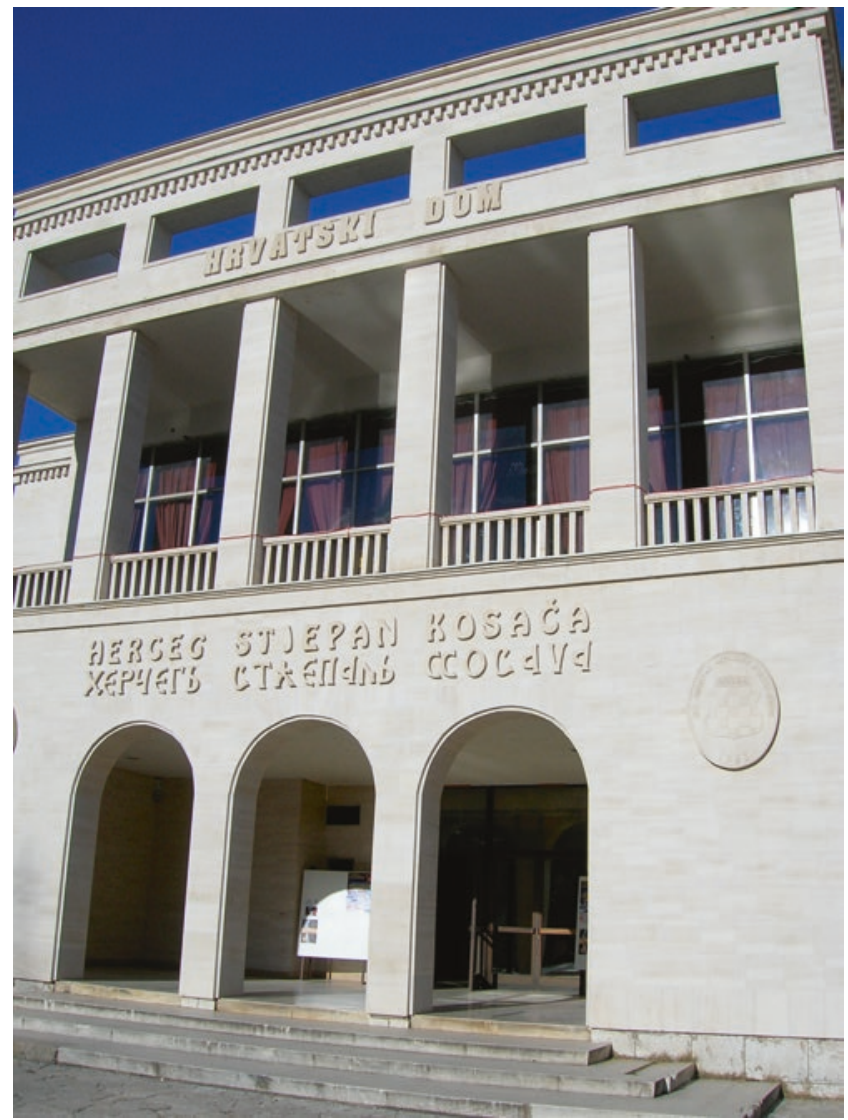

Fig. 1.1 Hrvatski Dom at Rondo. Photo by the author

street names tell us much about the historical consciousness of the people who encounter them every day (Palmberger 2017). Instead, they first and foremost express the voices of those who claim to speak for the nation.

In the introduction to the volume The Art of Forgetting one of the editors suggests: 'We cannot take it for granted that artefacts act as the agents of collective memory, nor can they be relied upon to prolong it' (Forty 1999: 7). Memorials and commemoration sites need people to note and read them, which means first of all people have to take notice of them. In 


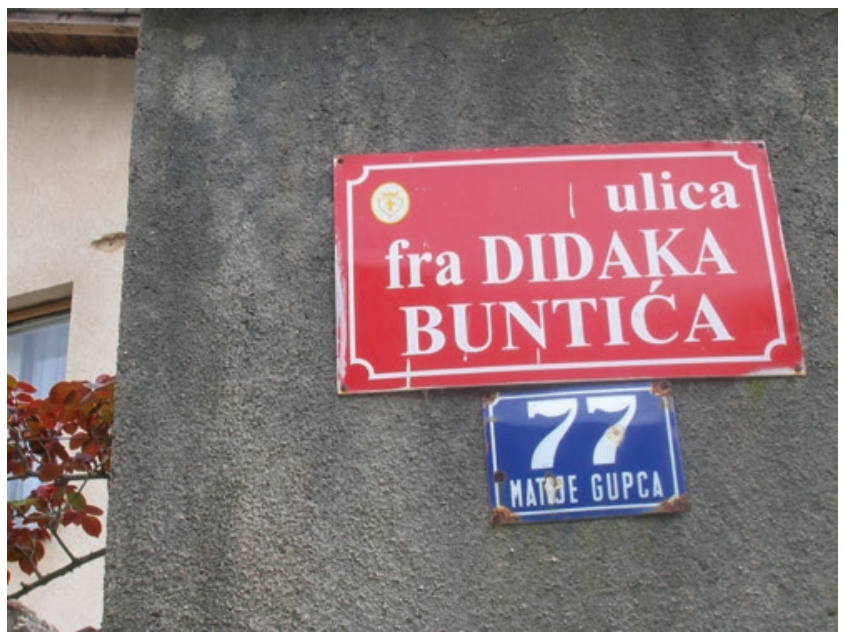

Fig. 1.2 Ulica fra Didaka Buntića is a new street name, named after a Catholic priest born in 1871. The old street name (in the sign below) was dedicated to Matija Gubec, a Croat farmer who was a leader of a farmers' uprising in the sixteenth century. During WWII his name was associated with the socialist Yugoslav Partisans and a Croat and a Slovene Partisan brigade were named after Gubec. Photo by the author

the case of the renamed streets in Croat-dominated West Mostar, people have not (yet) switched to using the new names, but rather refer to the streets by their old names. I also noticed a discrepancy between the prescribed meaning (by the ruling elites) and the people's interpretations and 'reading' of war memorials; the latter often significantly differed from the former (see Kansteiner 2002).

Another 'identity marker', though not visible in the cityscape, is language. But the languages on the Bosniak-dominated east side and the Croatdominated west side of Mostar are only minimally distinguishable and one often has to listen carefully to conversations in order to grasp 'typical' Croat or 'typical' Bosniak words. Still, language is an important identity marker, particularly for Croats. Most Croats in Mostar refer to their language as Croatian (in contrast to Bosnian, Serbian or Serbo-Croatian). The distinctive Croat language also serves as a central argument for a separate education system. The Croat-dominated university in Mostar is referred to as the only 
Croat university in $\mathrm{BiH}$, since it is the only university in $\mathrm{BiH}$ where students are taught in Croatian (see Chap. 3). Bosniaks speak of their language as 'Bosnian', while Croats often refer to it as 'Bosniak' (bošnjački), claiming that no shared Bosnian language exists. But many Croats also do not believe that the Bosniaks possess their own language. As we will learn in the next chapter, the language issue plays a central role in the division of Mostar's education system. The division of education along national lines institutionalises the division of Mostar into a Bosniak east and a Croat west side.

As shown above, a physical border no longer exists, but the Bulevar (the main street before the war and frontline during the war) persists as an 'imagined' border dividing the people of Mostar, as the majority of them have little if any contact with those on the 'other side' in their everyday life (Hromadžić 2015; Palmberger 2013b). While Mostar's 'border' is not a physical, it is a border created by economic, political and cultural forces and manifested in everyday social practices (Aure 2011: 173). ${ }^{19}$ 'Interpreted along these lines, a border is not so much an object or a material artefact as a belief, an imagination that creates and shapes a world, a social reality' (Houtum et al. 2005: 3). Houtum et al. with the notion of 'b/ordering' remind us that practices of border making are also practices of order making. Moreover, a border is likely to have two meanings. It may be interpreted as an obstacle to be overcome for some, while for others it may be associated with protection and safety. In Mostar's post-war setting, it is important to acknowledge the manifold experiences and interpretations of this b/order. While for part of the population a border between Bosniak- and Croat-dominated Mostar is welcomed as a protection of national 'rights', for others such a border is an obstacle to regaining a normal life (normalan život) (see Greenberg 2011; Jansen 2015; Palmberger 2013a, b; Spasić 2012; see also Chap. 2 this volume).

For me, as a foreigner living in $\mathrm{BiH}$ for three years, the 'border' between the Bosniak and Croat parts of the city as well as the war were ever present. Simply in walking through Mostar, I was reminded every day of the war by

\footnotetext{
${ }^{19} \mathrm{~B}$ /ordering practices in Mostar can also be found in everyday bureaucratic procedures, as Vetters (2009) vividly describes for the case of residence registration in Mostar.
} 
the high number of ruins. This included my immediate surroundings. Just at the doorstep to the house containing our first flat, a dud grenade was stuck in the ground, another stark reminder of the recent war. As I learned from the Croat landlords of our second flat, the building had a turbulent history. Built in the 1980s, the house was severely damaged during the war. Still, many people (presumably Bosniaks) from the neighbourhood sought shelter there during the war since it had a well-protected cellar. But the house had also served as a lockup for prisoners of war and as a temporary school where a small group of children were taught.

Another daily reminder of the legacy of the war was the fact that everyone I got to know seemed to be interested in which side I was loyal to. Even spontaneous conversations on the street, at gallery openings, in the playground and so on all tended to end with people directly or indirectly questioning me about which side of the city I lived on. In addition, religious holidays - which I had always experienced as a private rather than a political matter-for the first time in my life seemed politically charged. I realised this, for example, when I bought a Christmas tree, which, of course, had to be purchased on the Catholic west side, and then carried to our flat, which was located in immediate proxmity to the border, but already on the east side. The Christmas tree in my hand felt like a political statement. I felt similarly exposed when reading what were considered to be newspapers of the 'others' in public, or when using an expression that is today regarded as one of the other side's. For example, when ordering coffee on the east side it is common to say kafa for coffee, while on the west side it is kava; in the bakery people are now expected to use hljeb for bread on the east side, while on the west side one expects to hear kruh. Although most people I met pretended to ignore such subtleties, especially due to my status as a foreigner, I was also corrected several times (particularly by Croats) when I was too slow to switch from one side's terminology to the other.

\section{Notes on Methods}

The research on which this book is grounded was conducted in Mostar between October 2005 and August 2008, with additional return visits in 


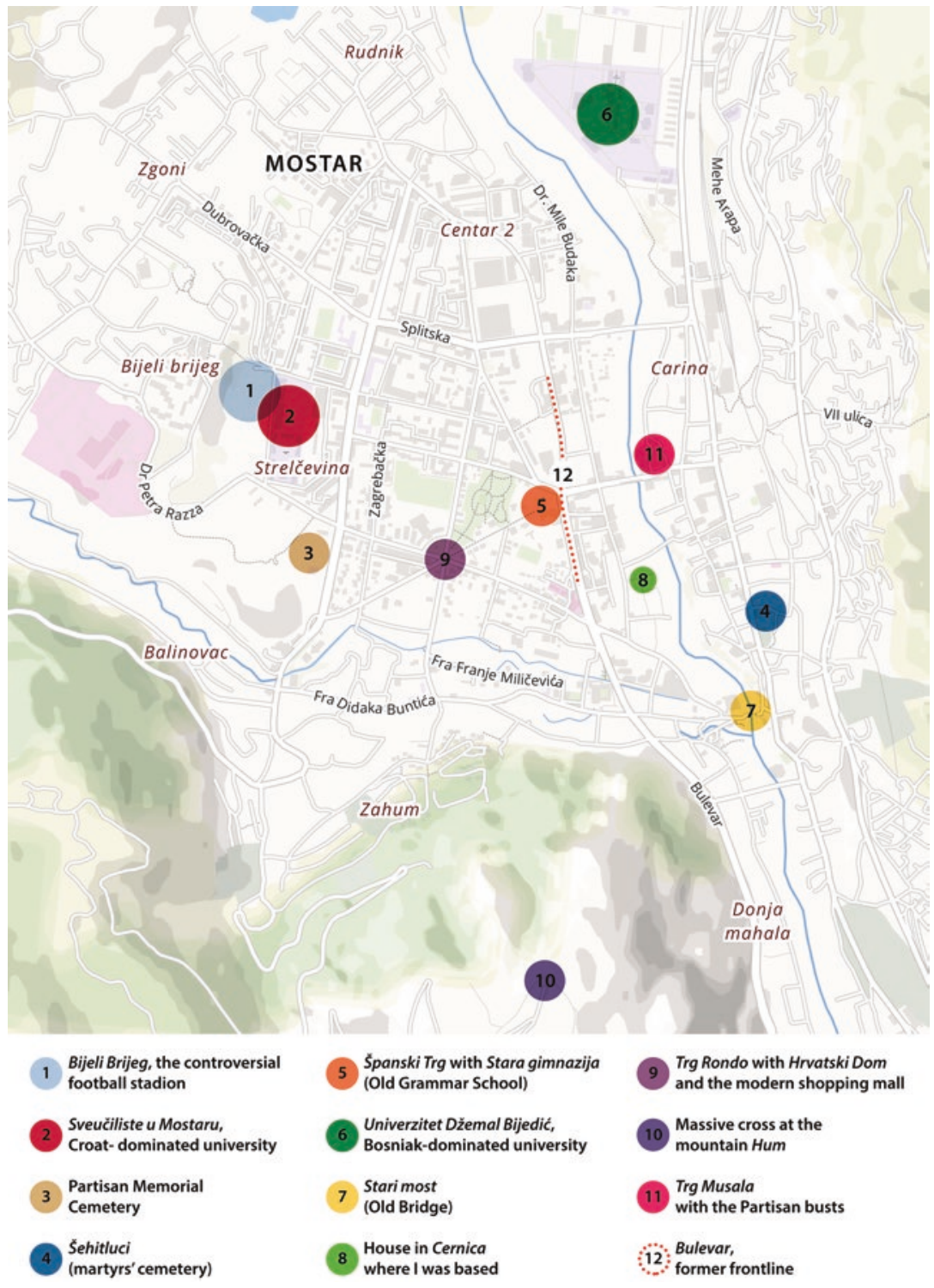

Map 1.3 Map of Mostar showing the former frontline and some 'field sites'. Map by Alexei Matveev. Map data () OpenStreetMap contributors 
2010 and in $2014 .{ }^{20}$ Despite the fact that its population numbers around $111,000,{ }^{21}$ Mostar has a town-like character (Map 1.3). Cernica-the part of Mostar where I lived together with my family, and one of the oldest residential areas-was especially known for its village-like character and the prevalence of gossip. Although I did not choose the location for this reason-but rather because it was centrally located and directly on the border between East and West Mostar-I certainly benefited from the neighbourhood's character. It did not take long before many of Cernica's residents knew me, including neighbours but also shopkeepers and bar and café owners. The flip side of this, however, was that as in any small neighbourhood people I had never spoken to knew a fair bit about me and my family. Our flat in Cernica soon became an 'open house'. From the beginning the childminder of our twin sons came every working day and my language teacher came on a regular basis, as did our childminder's friends and family members as well as friends we made during our stay.

The long period of my fieldwork of three years enabled me to establish long-term relationships with many of my interlocutors. Moreover, I had the privilege to join commemoration ceremonies over a period of three years. In the second year I moved to Sarajevo with my family, but kept the apartment in Mostar and was able to spend sufficient time there. Although after the first year in Mostar I had established stable relationships and friendships, something rather unexpected took place when I moved to Sarajevo. These relationships did not weaken. On the contrary, they became stronger. My friends in Mostar showed interest in staying in touch with me and I received regular phone calls, text messages and emails. Each time we met again back in Mostar (or in Sarajevo) our relationships became more intimate since we could already reflect on a 'shared past' (Fabian 2007: 133).

During my fieldwork I utilised a mixture of qualitative methods, including participant observation, semi-structured narrative interviews, informal conversations and memory-guided city tours. The most common denominator running through my diverse research methods is 'listening to narratives'. Narratives were told to me in informal/private

\footnotetext{
${ }^{20}$ During my visit in 2014 I witnessed some of the protests that were staged in parallel to citizen plenums, demanding social justice in $\mathrm{BiH}$. Although I conducted interviews with the protestors in Mostar, these findings could not be included in this book.

${ }^{21}$ In 2007, the Federalni Zavod za Statistiku estimated the population of Mostar to be 111,198 .
} 
and formal/public settings, for example, at universities or at commemorations as well as during interviews and informal conversations, sometimes during a city stroll or while looking at photos and other artefacts. Public events such as book presentations and discussion rounds plus media representations are also included in the analysis. The focus is thus on oral (and to a lesser extent written) narratives.

I took 'listening' as a research method very seriously, and during the first months of my fieldwork I did not conduct formal interviews but decided to first see what material came from my interlocutors. Only at a later stage (if at all) did I ask about the 'missing parts' in their narratives. This was a highly sensitive endeavour in which I always had to keep in mind not to push too hard when my interlocutors signalled that they were reluctant to elaborate on a certain topic.

These initial unstructured conversations with a loose agenda helped me to identify silences, the periods or events my interlocutors opted to leave out in their narratives. Though most authors agree that memory cannot be studied without its counterpart forgetting, few studies explicitly deal with forgetting, gaps and silences. Dealing with gaps and silences confronts the researcher with methodological difficulties. It is not only hard to interpret silences but even harder to locate them. Passerini quite rightly asks: 'How can we find traces of forgetting and silence since they are not themselves observable? We know that certain silences are observable only when they are broken or interrupted, but we want nonetheless to find them' (Passerini 2003: 239; see also Connerton 2008; Fabian 2007). It is true that the ability of researchers to identify and interpret silences is restricted, but longterm fieldwork is a way of meeting this methodological challenge since relationships of trust often are achieved only after months or even years.

Although I tried to avoid leading conversations along a clearly defined agenda, my interlocutors sometimes pursued such an agenda themselves. In such cases, their narratives were ready-made and presumably had been told several times before. I gained the impression that during their narration they were not so much remembering the event they were telling me about, but rather the last occasion they had told the story (see Bloch 1998). In such encounters my interlocutors clearly had an interest in sharing the 'truth about the past' and these discourses were hard to ignore. But narrative abilities are not equally distributed, so it was particularly important 
for me to listen carefully to those who were less articulate and often also less involved in political life (see Bourdieu 1999). This was in accordance with my aim of eliciting the views of ordinary people rather than just the opinion-formers in the community. Throughout my field research, I acted on the assumption that my interlocutors' narratives would show which events were crucial in their lives and how they position themselves in relation to them (see Misztal 2003). Therefore, I first collected the narratives and only during the process of analysis did I identify the three generations and their particular differences (see Palmberger and Gingrich 2013).

One approach that proved invaluable for engaging interlocutors in a rather unstructured reflection on personal and local history was to ask them for memory-guided city tours. I left it to the person guiding me through the city to decide which places to visit. Often, the city tour was a stroll around Mostar where my 'guides' showed me places that they regarded as important. The sites were chosen either because of their national heritage value (e.g., the Old Bazaar, mosques or churches) or else because they possessed autobiographical meaning for my guides (e.g., schools, residential houses or other places with which they share a special history). Sometimes the sites shown to me were presented as important because of both, that is, valuable or meaningful for their national and personal autobiographical past, such as the Old Bridge.

Every tour through Mostar I was taken on was different in character, not only because of the different tour guides but also because of the different contexts within which the tours took place. Sometimes I explicitly asked Mostarians to show me around 'their city', and it was only they and I who strolled around Mostar. At other times when I had foreign visitors I used the opportunity to ask a local friend to show us around Mostar. Depending on whether we were only a small group of friends or a big group of foreign students, the tours had a more informal or formal character. Rather than using memory-guided city tours as a standardised method, I saw them as opportunities to hear Mostarians reflect on the history of their city and of their lives closely interwoven with it. The act of comparing post-war Mostar with pre-war Mostar was inherent in every tour I was given, with the exception of the tours given by my youngest interlocutors (see Chap. 6). The sites visited often reflected Mostar's and my guides' histories, ruptured due to the war. Sites were often destroyed, rebuilt or replaced, or at least their 
meaning had changed during the course of the far-reaching changes experienced by Mostar's society.

Two criteria were particularly important to me when choosing my methods and field sites (Map 1.3). Firstly, I aimed to find sites that would give me access to people of different ages, genders and national backgrounds. Since the great majority of Mostar's inhabitants declare themselves to be either Bosniaks or Croats, almost all of my interlocutors belonged to one of these two groups; therefore I decided to focus first and foremost on them. However, some of my interlocutors did have Serb backgrounds, came from mixed marriages or declared themselves to be Yugoslavs. Secondly, I searched for field sites that would allow me to explore public memory discourses as well as individual narratives of the past.

During my entire field stay, but predominantly in my first year of fieldwork, I attended numerous commemoration events, reburials, anniversaries, demonstrations, relevant round tables and book presentations. Commemorations were attributed either to the victims and heroes of WWII or of the war in the 1990s and - to a lesser extent-to prominent local artists. Since the annual calendar in Mostar is full of such commemorations, which are open to the public, these were good entry points for my research. At these events I learned more about public memory discourses and had the opportunity to talk to both the participants and the event organisers. Even if I also paid attention to ritual aspects of these ceremonies, they were not central to the focus of this research. Rather than simply assuming that commemorations are the prime means for maintaining and transferring collective identity, I investigate these events in order to outline the wider social context in which they are embedded (see Vertovec and Rogers 1995).

All the people presented in this book are real, although I have changed names, places and other personal details where necessary in order to grant anonymity. Most of the interviews were conducted in the local language, and the interview citations presented in this book are English translations. If an interview was conducted in English, I indicate in a footnote that the citation is the original. All interviews (and other cited recordings) are in my possession. In this book, I can only present a small number of narratives that were shared with me; this is also the case for the commemorations I attended. Furthermore, it should also be said that none of the individuals discussed represents their generation or their nation as such; however, their individual narratives provide an opening through which we can explore the 
central themes of the book. In the choice of individual narratives to present in this book I aimed to give voice to individuals of Bosniak as well as Croat national backgrounds as well as to those who do not identify as either/or.

\section{Structure of the Book}

This book is organised around five chapters and a conclusion. Chapter 2 provides a historical contextualisation of the field by providing the most important benchmarking data about the periods of which people I talked to have personal memories. Moreover, different 'memory politics' they have been exposed to during their lifetimes (from WWII to the present day) are discussed. In Chap. 3, the historical contextualisation is followed by ethnographic data, based primarily on material gathered at the two universities in Mostar. By presenting this ethnographic data I reveal key representations found in the dominant Bosniak as well as Croat public history discourses. I pay particular attention to the historians' discursive strategies in order to nationalise, legitimise and objectify the respective historiographies.

In Chaps. 4-6, the centrepiece of the book, each of the three generations identified is discussed. Not only are the particular features of each generation carved out but also each chapter tackles some theoretical issues, which are subsequently discussed. The analysis of the three generations starts in Chap. 4 with the First Yugoslavs. The First Yugoslavs, the oldest generation identified, form the generation that still has personal memories of WWII. Some experienced the war as children, some as young adults. The experience of WWII in this early stage of life was crucial and serves as an interpretative template for their later experiences, in particular for the war in the 1990s. Not only WWII but also the founding years of Yugoslavia were formative for this generation-a generation that to a great degree to this day remains loyal to Tito. The First Yugoslavs are, moreover, in a stage of life that allows them to delve most freely into the past and cherish memories shared with others of the same generation.

Although the recent war has certainly been experienced as a disruption in the lives of the First Yugoslavs, it is not the central reference point but rather is incorporated into a wider narrative, often a narrative of suffering. However, the recent war was not only linked to WWII in this narrative of suffering but WWII was also taken as an interpretative template to explain 
the war in the 1990s. Thus, linking recent experiences to those early in their lives is a central discursive tactic employed in the narratives of the oldest generation. In the second part of the chapter, the discussion moves from an individual/personal to a more collective/public level. Based on observations at a Partisan commemoration ceremony, I analyse how members of the First Yugoslav generation engage in keeping the memory of the Partisan fight alive even while it loses its once supra-ethnic character. The chapter ends with a discussion of WWII as an interpretative template and its uses in personal meaning making by the First Yugoslav generation as well as a political tool to strengthen the dominant Bosniak national discourse.

While the First Yugoslavs find themselves in a life situation which to a certain degree allows them to retreat into the past, the Last Yugoslavs, discussed in Chap. 5, are, so to say, in mid-life and the war in the 1990s for many of this generation changed their expected life course dramatically. The youngest of them were in their late teens when the war broke out, while the oldest had already established their own households. The Last Yugoslavs have no personal memories of WWII and few, if any, memories of the first years of Tito's Yugoslavia. Social security and economic well-being are central to their experience of Yugoslavia. As shown in the book, the lives of the Last Yugoslavs were shaken most by the rupture of the war in the 1990s and the end of socialist Yugoslavia.

Due to the life situations they find themselves in, the particular challenge for the Last Yugoslavs is to re-orient themselves in the new post-war socio-political context. The need to (re-)orient themselves after the war is most urgent and immediate for the Last Yugoslavs as they find themselves in the middle of their lives (including their working and family lives). The war not only took away their homes but also their future prospects. The discursive tactics of the Last Yugoslavs are characterised by oscillation between different discourses_-old and new-and this generation struggles to narrate their lives and the history of their society in a meaningful and coherent way. Many of the Last Yugoslavs have incorporated key elements of the dominant public discourses into their narratives but at the same time maintain nostalgia for Yugoslav times. The main strands of discussion in Chap. 5 centre on the notion of nostalgia, the experience of loss of home and the subsequent difficulties in telling a coherent narrative.

In Chap. 6, I turn my attention to the youngest generation, the PostYugoslavs, who experienced the war in the 1990s as children. They have 
either very few or no personal memories of Yugoslavia, and their memories are primarily located in the context of their families. The older generations perceive the Post-Yugoslavs as a generation that is spoilt by nationalist propaganda and one lacking the experience of pre-war Mostar (particularly the experience of good neighbourliness among the different national groups). Meanwhile, the Post-Yugoslavs present their relatively young age as a 'shield' that has protected them from bad experiences. Due to their young age at the time of the war, the Post-Yugoslavs claim a neutral position for themselves. They argue that they are less affected by the negative feelings caused by war, such as hate and distrust towards the 'other'. Thereby their discursive tactics are characterised by dissociating their lives from the wider societal (national) experiences concerning the war.

A vital discussion in Chap. 6 centres on the counterpart of remembering: silencing. The Post-Yugoslav generation's discursive tactics serve to silence the effect of the war on their lives. As such, the Post-Yugoslavs do not subordinate their lives to the wider narratives of victimisation and suffering of their respective nations so prominent in the dominant public discourses and in narratives of the two older generations. It is suggested that they do so for at least two reasons. Firstly, it is a way to distance their lives from those of their parents and older family members, not least to maintain hope for their city to which their future is closely connected. Secondly, their silence can also be interpreted as a sign that this generation has not yet formed its own narrative of the recent past.

Although the Post-Yugoslavs do not indulge fully in the dominant public discourses when it comes to their lives, they have to a large degree accepted the national division as primordial, as is presently promoted within the school curriculum. The chapter includes a discussion about the way the Post-Yugoslavs give meaning to the experiences of the older generations and analyses processes of transmission of (collective) memory.

In the Conclusion, the central arguments of the book are summarised and conclusions are drawn from the analysis of the material presented and set in relation to relevant research in other regional and socio-historic contexts. Moreover, I point to areas of future research that could be explored in order to further develop theories on memory and generation, including the concept of 'generational positioning' developed in this book. 


\section{Bibliography}

Altinary, Ayşe, and Andrea Petö, eds. 2015. Gendered Wars, Gendered Memories: Feminist Conversations on War, Genocide and Political Violence. Aldershot: Ashgate.

Ange, Olivia, and David Berliner. 2015. Anthropology and Nostalgia. New York: Berghahn.

Antze, Paul, and Michael Lambek. 1996a. Tense Past: Cultural Essays in Trauma and Memory. New York: Routledge.

- 1996b. Introduction: Forecasting Memory. In Tense Past: Cultural Essays in Trauma and Memory, eds. P. Antze and M. Lambek, xi-xxxvii. New York: Routledge.

Argenti, Nicolas, and Katharina Schramm. 2010. Remembering Violence: Anthropological Perspectives on Intergenerational Transmission. New York: Berghahn.

Ashplant, Timothy, Graham Dawson, and Michael Roper. 2009. The Politics of War Memory and Commemoration: Contexts, Structure and Dynamics. In The Politics of War Memory and Commemoration: Contexts, Structure and Dynamics, eds. T. Ashplant, G. Dawson, and M. Roper, 3-85. London: Routledge. Original edition, 2004.

Assmann, Aleida. 1999. Erinnerungsräume: Formen und Wandlungen des kulturellen Gedächtnisses. Munich: Beck.

Assmann, Jan. 2007. Das kulturelle Gedächtnis. Schrift, Erinnerung und politische Identität in frühen Hochkulturen. Munich: Beck. Original edition, 1992.

Assmann, Jan, and John Czaplicka. 1995. Collective Memory and Cultural Identity. New German Critique 65: 125-133.

Augustinović, Anto. 1999. Mostar: ljudi, kultura, civilizacija. Mostar: Hrvatska kulturna zajednica u Federaciji BiH.

Aure, Marit. 2011. Borders of Understanding: Re-Making Frontiers in the Russian-Norwegian Contact Zone. Ethnopolitics 10(2): 171-186.

Bach, Jonathan. 2002. The Taste Remains: Consumption, (N)Ostalgia, and the Production of East Germany. Public Culture 14(3): 545-556.

Ballinger, Pamela. 2003. History in Exile: Memory and Identity at the Borders of the Balkans. Princeton, NJ: Princeton University Press.

Bartmanski, Dominik. 2011. Successful Icons of Failed Time: Rethinking PostCommunist Nostalgia. Acta Sociologica 54(3): 213-231.

Basic-Hrvatin, Sandra. 1996. Television and National/Public Memory. In Bosnia by Television, eds. J. Gow, R. Paterson, A. Preston, and British Film Institute, 63-71. London: British Film Institute. 
Berg, Mette L. 2009. Between Cosmopolitanism and the National Slot: Cuba's Diasporic Children of the Revolution. Identities: Global Studies in Culture and Power 16(2): 129-156.

Berliner, David. 2005. The Abuses of Memory: Reflections on the Memory Boom in Anthropology. Anthropological Quarterly 78(1): 197-211.

Bertaux, Daniel, and Paul R. Thompson. 1993. Between Generations: Family Models, Myths, and Memories, International Yearbook of Oral History and Life Stories. Oxford: Oxford University Press.

Bet-El, Ilana R. 2002. Unimagined Communities: The Power of Memory and the Conflict in the Former Yugoslavia. In Memory and Power in Post-War Europe: Studies in the Presence of the Past, ed. J.-W. Müller, 206-222. Cambridge: Cambridge University Press.

Bieber, Florian. 2005. Local Institutional Engineering: A Tale of Two Cities, Mostar and Brcko. International Peacekeeping 12(3): 420-433.

Birth, Kevin. 2006. Past Times: Temporal Structuring of History and Memory. Ethos 34(2): 192-210.

Bjelakovic, Nebojsa, and Francesco Strazzari. 1999. The Sack of Mostar, 19921994: The Politico-Military Connection. European Security 8(2): 73-102.

Bloch, Maurice. 1998. How We Think They Think: Anthropological Approaches to Cognition, Memory, and Literacy. Boulder, CO: Westview Press.

- 2007. How Culture Squeezes in between Social Memory and Autobiographical Memory (Conference Paper). How Collectivities Remember: Structures and Spaces of Social and Cultural Memory. Tallinn, Estonia, 27 July-2 August 2007.

Borneman, John. 1992. Belonging in the Two Berlins: Kin, State, Nation, Cambridge Studies in Social and Cultural Anthropology. Cambridge: Cambridge University Press.

Bose, Sumatra. 2002. Bosnia after Dayton: Nationalist Partition and International Intervention. London: Hurst \& Company.

Botev, Nikolai, and Richard Wagner. 1993. Seeing Past the Barricades: Ethnic Intermarriage in Yugoslavia During the Last Three Decades. Anthropology of East Europe Review 11 (1-2). http://condor.depaul.edu/ -rrotenbe/aeer/ aeer11_1/botev.html [17.07.2009].

Bougarel, Xavier. 2007. Death and the Nationalist: Martyrdom, War Memory and Veteran Identity among Bosnian Muslims. In The New Bosnian Mosaic: Identities, Memories and Moral Claims in a Post-War Society, eds. X. Bougarel, E. Helms, and G. Duijzings, 167-192. Aldershot: Ashgate.

Bourdieu, Pierre. 1998. Praktische Vernunft: Zur Theorie des Handelns. Frankfurt/ Main: Suhrkamp. 
1999. The Weight of the World: Social Suffering in Contemporary Society.

Cambridge: Polity. Original edition, 1993.

Boyer, Dominic. 2006. Ostalgie and the Politics of the Future in Eastern Europe.

Public Culture 18(2): 361-382.

Boym, Svetlana. 2001. The Future of Nostalgia. New York: Basic Books.

Bringa, Tone. 1995. Being Muslim the Bosnian Way: Identity and Community in

a Central Bosnian Village, Princeton Studies in Muslim Politics. Princeton, NJ:

Princeton University Press.

Brown, Keith. 2003. The Past in Question: Modern Macedonia and the Uncertainties of Nation. Princeton, NJ: Princeton University Press.

Brunnbauer, Ulf, and Stefan Troebst. 2007. Zwischen Amnesie und Nostalgie: Die

Erinnerung an den Kommunismus in Südosteuropa, Visuelle Geschichtskultur.

Cologne: Böhlau.

Bude, Heinz. 1997. Das Altern einer Generation: Die Jahrgänge 1938 bis 1948. Frankfurt/Main: Suhrkamp.

-. 2005. "Generation" im Kontext. Von den Kriegs- zu den Wohlfahrtsstaatsgenerationen. In Generationen: Zur Relevanz eines wissenschaftlichen Grundbegriffs, eds. U. Jureit and M. Wildt, 28-44. Hamburg: Hamburger Ed.

Burke, Peter. 1989. History as Social Memory. In Memory: History, Culture and the Mind, ed. T. Butler, 97-113. Oxford: Basil Blackwell.

Campbell, Matthew, Jacqueline M. Labbe, and Sally Shuttleworth. 2000. Memory and Memorials, 1789-1914: Literary and Cultural Perspectives. London: Routledge.

Certeau, Michel de. 1980. On the Oppositional Practices of Everyday Life. Social Text 3: 3-43.

- 1984. The Practice of Everyday Life. Berkeley: University of California Press.

Cole, Ardra L., and J. Gary Knowles. 2001. Lives in Context: The Art of Life History Research. Walnut Creek, CA: Altamira Press.

Confino, Alon. 1997. Collective Memory and Cultural History: Problems of Method. The American Historical Review 102(5): 1386-1403.

Connerton, Paul. 1989. How Societies Remember. Cambridge: Cambridge University Press.

2008. Seven Types of Forgetting. Memory Studies 1(1): 59-71.

Corning, Amy. 2010. Emigration, Generation, and Collective Memories. Social Psychology Quarterly 73(3): 223-244.

Crane, Susan A. 1997. Writing the Individual Back into Collective Memory. The American Historical Review 102(5): 1372-1385. 
Creed, Gerald. 2006. Domesticating Discontent: The Work of Nostalgia in Bulgaria (Conference Paper). Post-Communist Nostalgia. University of Illinois, Urbana-Champaign, 7-8 April 2006.

Davis, Fred. 1977. Nostalgia, Identity and the Current Nostalgia Wave. Journal of Popular Culture 11(2): 414-424.

Denich, Bette. 1994. Dismembering Yugoslavia: Nationalist Ideologies and the Symbolic Revival of Genocide. American Ethnologist 21(2): 367-390.

Diewald, Martin, Anne Goedicke, and Karl U. Mayer. 2006. After the Fall of the Wall: Life Courses in the Transformation of East Germany, Studies in Social Inequality. Stanford: Stanford University Press.

Donia, Robert J. 2000. Review Article. The New Bosniak History. Nationalities Papers 28(2): 351-358.

Erll, Astrid. 2011a. Locating Family in Cultural Memory Studies. Journal of Comparative Family Studies 42(3): 303-318.

— 2011b. Memory in Culture. Basingstoke: Palgrave Macmillan.

Fabian, Johannes. 2006. The Other Revisited: Critical Afterthoughts. Anthropological Theory 6: 139-152.

- 2007. Memory against Culture: Arguments and Reminders. Durham: Duke University Press.

Feindt, Gregor, Félix Krawatzek, Daniela Mehler, Friedemann Pestel, and Rieke Trimçev. 2014. Entangled Memory: Toward a Third Wave in Memory Studies. History and Theory 53(1): 24-44.

Fentress, James, and Chris Wickham. 1992. Social Memory, New Perspectives on the Past. Oxford: Blackwell.

Feuchtwang, Stephan. 2005. Mythical Moments in National and Other Family Histories. History Workshop Journal 59: 179-193.

Fietze, Beate. 2009. Historische Generationen: Über einen sozialen Mechanismus kulturellen Wandels und kollektiver Kreativität. Bielefeld: Transcript.

Forty, Adrian. 1999. Introduction. In The Art of Forgetting, eds. A. Forty and S. Küchler, 1-18. Oxford: Berg.

Foucalt, Michel. 1977. Language, Counter-Memory, Practice. Ithaca, NY: Cornell University Press.

French, Brigittine. 2012. The Semiotics of Collective Memories. Annual Review of Anthropology 41: 337-353, Annual Reviews.

Friedman, Jonathan. 1992. The Past in the Future: History and the Politics of Identity. American Anthropologist 94(4): 837-859.

Gal, Susan. 2002. Between Speech and Silence. In The Anthropology of Politics: A Reader in Ethnography, Theory, and Critique, ed. J. Vincent, 213-221. Malden, MA: Blackwell. 
Gardner, Katy. 2002. Age, Narrative and Migration: The Life Course and Life Histories of Bengali Elders in London. Oxford: Berg.

Glick Schiller, Nina, Ayse Caglar, and Thaddeus Guldbrandsen. 2006. Beyond the Ethnic Lens: Locality, Globality, and Born-Again Incorporation. American Ethnologist 33(4): 612-633.

Gordy, Eric. 2013. Guilt, Responsibility, and Denial: The Past at Stake in PostMilošević Serbia. Philiadelphia, PA: University of Pennsylvania.

Greenberg, Jessica. 2011. On the Road to Normal: Negotiating Agency and State Sovereignty in Postsocialist Serbia. American Anthropologist 113(1): 88-100.

- 2014. After the Revolution: Youth, Democracy, and the Politics of Disappointment in Serbia. Stanford, CA: Stanford University Press.

Halbwachs, Maurice. 1925. Les Cadres sociaux de la Mémoire, Travaux de l'Année sociologique. Paris: F. Alcan.

- 1980. The Collective Memory. New York: Harper Colphon Books. Original edition, 1950.

- 1992. On Collective Memory. Chicago: The University of Chicago Press. Hall, Jacquelyn D. 1998. "You Must Remember This": Autobiography as Social Critique. The Journal of American History 85(2): 439-465.

Haukanes, Haldis, and Susanna Trnka. 2013. Memory, Imagination, and Belonging across Generations: Perspectives from Postsocialist Europe and Beyond. Focaal 66: 3-13.

Hayden, Robert. 1994. Recounting the Dead. The Rediscovery and Redefinition of Wartime Massacres in Late- and Post-Communist Yugoslavia. In Memory, History, and Opposition under State Socialism, ed. R. Watson, 167-189. Santa Fe, NM: School of American Research Press.

Heady, Patrick, and Liesl L. Gambold Miller. 2006. Nostalgia and the Emotional Economy: A Comparative Look at Rural Russia. In Postsocialism: Politics and Emotions in Central and Eastern Europe, ed. M. Svasek, 34-52. New York: Berghahn.

Helms, Elissa. 2010. The Gender of Coffee: Women and Reconciliation Initiatives in Post-War Bosnia and Herzegovina. Focaal 57: 17-32.

- 2013. Innocence and Victimhood: Gender, Nation, and Women's Activism in Postwar Bosnia-Herzegovina. Madison, WI: University of Winsconsin Press. Henig, David. 2012. "Knocking on My Neighbour's Door”: On Metamorphoses of Sociality in Rural Bosnia. Critique of Anthropology 32(1): 3-19.

Hirsch, Marianne. 2008. The Generation of Postmemory. Poetics Today 29(1): 103-128.

Hodgkin, Katharine, and Susannah Radstone. 2006. Introduction: Contested Pasts. In Memory, History, Nation: Contested Pasts, eds. K. Hodgkin and S. Radstone, 1-21. New York: Routledge. 
Holland, Dorothy C., and Jean Lave. 2001. History in Person: An Introduction. In History in Person: Enduring Struggles, Contentious Practice, Intimate Identities, eds. D.C. Holland and J. Lave, 3-36. Santa Fe: School of American Research Press. Höpken, Wolfgang. 2007. Post-sozialistische Erinnerungskulturen im ehemaligen Jugoslawien. In Südosteuropa. Traditionen als Macht, eds. E. Brix, A. Suppan, and E. Vyslonzil, 13-50. Munich: Verlag für Geschichte und Politik Wien.

Houtum, Henk van, Olivier T. Kramsch, and Wolfgang Zierhofer. 2005. B/Ordering Space. Aldershot: Ashgate.

Hromadžić, Azra. 2015. Citizens of an Empty Nation: Youth and State-Making in Postwar Bosnia-Herzegovina. Philadelphia: University of Pennsylvania Press.

Hutton, Patrick H. 1993. History as an Art of Memory. Hannover: University Press of New England.

ICG. 2000. Reunifying Mostar: Opportunities for Progress. International Crisis Group Balkan Report No. 90. Sarajevo: ICG.

Irwin-Zarecka, Iwona. 1994. Frames of Remembrance: The Dynamics of Collective Memory. New Brunswick: Transaction Publishers.

Jansen, Stef. 2002. The Violence of Memories: Local Narratives of the Past after Ethnic Cleansing in Croatia. Rethinking History 6(1): 77-94.

- 2005. Who's Afraid of White Socks? Towards a Critical Understanding of Post-Yugoslav Urban Self-Perceptions. Ethnologia Balkanica 9: 151-167.

- 2015. Yearnings in the Meantime: 'Normal Lives' and the State in a Sarajevo Apartment Complex. New York: Berghahn.

Jureit, Ulrike. 2009. Identitätsarbeit: Ein Kommentar zu biographischen Erinnerungen in (post)sozialistischen Gesellschaften. In Erinnerungen nach der Wende: Oral History und (post)sozialistische Gesellschaften: Remembering after the Fall of Communism, ed. J. Obertreis, 85-90. Essen: Klartext-Verlag. Kansteiner, Wolf. 2002. Finding Meaning in Memory: A Methodological Critique of Collective Memory Studies. History and Theory 41(2): 179-197.

Kay, Rebecca, Sergei Shubin, and Tatjana Thelen. 2012. Rural Realities in the Post-Socialist Space. Journal of Rural Studies 28: 55-62.

Kerby, Anthony P. 1991. Narrative and the Self, Studies in Continental Thought. Bloomington: Indiana University Press.

Kidron, Carol A. 2009. Toward an Ethnography of Silence: The Lived Presence of the Past in the Everyday Life of Holocaust Trauma Survivors and Their Descendants in Israel. Current Anthropology 50(1): 5-27.

Kolind, Torsten. 2008. Post-War Identification: Everyday Muslim Counterdiscourse in Bosnia Herzegovina. Aarhus: Aarhus University Press.

Koselleck, Reinhart. 2004. Futures Past: On the Semantics of Historical Time. New York: Columbia University Press. 
Lambek, Michael. 2003. Memory in a Maussian Universe. In Regimes of Memory, eds. S. Radstone and K. Hodgkin, 202-216. London: Routledge.

Leydesdorff, Selma, Luisa Passerini, and Paul R. Thompson. 1996. Gender and Memory, International Yearbook of Oral History and Life Stories. Oxford: Oxford University Press.

Lisón Tolosana, Carmelo. 1966. Belmonte De Los Caballeros: A Sociological Study of a Spanish Town. Oxford: Clarendon Press.

Lowenthal, David. 1985. The Past is a Foreign Country. Cambridge: Cambridge University Press.

Lüscher, Kurt. 2005. Ambivalenz - Eine Annäherung an das Problem der Generation. In Generationen: Zur Relevanz eines wissenschaftlichen Grundbegriffs, eds. U. Jureit and M. Wildt, 53-78. Hamburg: Hamburger Edition.

Lüscher, Kurt, and Ludwig Liegle. 2003. Generationenbeziehungen in Familie und Gesellschaft. Constance: UVK.

Mannheim, Karl. 1997. The Problem of Generations. In Essays on the Sociology of Knowledge, ed. K. Mannheim. London: Routledge. Original edition, 1928. Mayer, Karl U. 2009. New Directions in Life Course Research. Annual Review of Sociology 35(1): 413-433.

Misztal, Barbara A. 2003. Theories of Social Remembering, Theorizing Society. Maidenhead: Open University Press.

Moll, Nicolas. 2013. Fragmented Memories in a Fragmented Country: Memory Competition and Political Identity-Building in Today's Bosnia and Herzegovina. Nationalities Papers 41(6): 910-935.

Natzmer, Cheryl. 2002. Remembering and Forgetting: Creative Expression and Reconciliation in Post-Pinochet Chile. In Social Memory and History: Anthropological Perspectives, eds. J.J. Climo and M.G. Cattell, 161-179. Walnut Creek: Altamira Press.

Nugin, Raili. 2010. Social Time as the Basis of Generational Consciousness. Trames 14(4): 342-366.

Ochs, Elinor, and Lisa Capps. 1996. Narrating the Self. Annual Review of Anthropology 25(1): 19-43.

- 2001. Living Narrative: Creating Lives in Everyday Storytelling. Cambridge, MA: Harvard University Press.

Olick, Jeffrey. 1999. Collective Memory: The Two Cultures. Sociological Theory 17(3): 333-348.

Olick, Jeffrey, and Joyce Robbins. 1998. Social Memory Studies: From 'Collective Memory' to the Historical Sociology of Mnemonic Practices. Annual Review of Sociology 24: 105-140.

Paletschek, Sylvia, and Sylvia Schraut. 2008. The Gender of Memory: Cultures of Remembrance in Nineteenth and Twentieth Century Europe. Frankfurt: Campus. 
Palmberger, Monika. 2013a. Ruptured Pasts and Captured Futures: Life Narratives in Post-War Mostar. Focaal - Journal of Global and Historical Anthropology 66: 14-24.

2013b. Acts of Border Crossing in Post-War Bosnia and Herzegovina: The Case of Mostar. Identities: Global Studies in Culture and Power 20(5): 544-560.

. 2013c. Renaming of Public Space: A Policy of Exclusion in Bosnia and Herzegovina. Kakanien Revisited 1-11.

- 2017. Nationalizing the Streetscape. The Case of Street Renaming in Mostar, Bosnia-Herzegovina. In The Political Life of Urban Streetscapes: Naming, Politics, and Place, eds. R. Rose-Redwood, D. Alderman, and M. Azaryahu. Farnham: Ashgate.

Palmberger, Monika, and Andre Gingrich. 2013. Qualitative Comparative Practices: Dimensions, Cases, and Strategies. In Sage Handbook of Analyzing Qualitative Data, ed. U. Flick. Thousand Oaks, CA: SAGE.

Palmberger, Monika, and Jelena Tošić. 2016. Memories on the Move: Experiencing Mobility, Rethinking the Past. Basingstoke: Palgrave Macmillan.

Parkin, Robert, and Linda Stone. 2004. Kinship and Family: An Anthropological Reader, Blackwell Anthologies in Social and Cultural Anthropology. Malden, MA: Blackwell.

Passerini, Luisa. 2003. Memories Between Silences and Oblivion. In Contested Pasts: The Politics of Memories, eds. K. Hodgkin and S. Radstone. London: Routledge.

- 2007. Memory and Utopia: The Primacy of Intersubjectivity, Critical Histories of Subjectivity and Culture. London: Equinox.

Paul. 2006. Memory, History, Forgetting. Chicago: The University of Chicago Press.

Pickering, Michael, and Emily Keightley. 2013. Communities of Memory and the Problem of Transmission. European Journal of Cultural Studies 16(1): $115-131$.

Pine, Frances. 2013. Probing the Past and Imagining the Future: Afterword. Focaal - Journal of Global and Historical Anthropology 66: 69-72.

Polkinghorne, Donald. 1998. Narrative Psychologie und Geschichtsbewußtsein. In Erzählung, Identität und historisches Bewußtsein: Die psychologische Konstruktion von Zeit und Geschichte, ed. J. Straub, 12-45. Frankfurt/Main: Suhrkamp.

Price, Monroe. 2002. Memory, the Media and Nato: Information Intervention in Bosnia-Herzegovina. In Memory and Power in Post-War Europe: Studies in the Presence of the Past, ed. J.-W. Müller, 137-184. Cambridge: Cambridge University Press. 
Purdeková, Andrea. 2008. Building a Nation in Rwanda? De-Ethnicisation and Its Discontents. Studies in Ethnicity and Nationalism 8(3): 502-523.

Rasmussen, Susan. 2002. The Uses of Memory. Culture and Psychology 8(1): 113-129.

Reulecke, Jürgen. 2010. Generation/Generationality, Generativity, and Memory. In A Companion to Cultural Memory Studies, eds. A. Erll and A. Nünning, 119-126. Berlin: de Gruyter.

Ricoeur, Paul. 2006. Memory, History, Forgetting. Chicago and London: The University of Chicago Press.

Ringel, Felix. 2013. Differences in Temporal Reasoning: Temporal Complexity and Generational Clashes in an East German City. Focaal - Journal of Global and Historical Anthropology 66: 25-35.

Rosenthal, Gabriele. 2006. The Narrated Life Story: On the Interrelation between Experience, Memory and Narration. In Narrative, Memory \& Knowledge: Representations, Aesthetics, Contexts, eds. K. Milnes et al., 1-16. Huddersfield: University of Huddersfield Repository.

Rosenthal, Gabriele, and Artur Bogner, eds. 2009. Ethnicity, Belonging and Biography: Ethnographical and Biographical Perspectives. Münster: LIT.

Rosenthal, Gabriele, and Claudia Gather, eds. 1986. Die Hitlerjugend-Generation: Biographische Thematisierung als Vergangenheitsbewältigung. Essen: Verlag die blaue Eule.

Rothberg, Michael. 2009. Multidirectional Memory: Remembering the Holocaust in the Age of Decolonization. Standford, CA: Stanford University Press.

Ryder, Norman. 1965. The Cohort as a Concept in the Study of Social Change. American Sociological Review 30(6): 843-861.

Saikia, Yasmin. 2004. Beyond the Archive of Silence: Narratives of Violence of the 1971 Liberation War of Bangladesh. History Workshop Journal 58(1): 275-287. Sant Cassia, Paul. 2005. Bodies of Evidence: Burial, Memory and the Recovery of Missing Persons in Cyprus, New Directions in Anthropology. New York: Berghahn Books.

Schäuble, Michaela. 2014. Narrating Victimhood: Gender, Religion and the Making of Place in Post-War Croatia. Space and Place. New York: Berghahn. Schramm, Katharina. 2011. Introduction: Landscapes of Violence: Memory and Sacred Space. History \& Memory 23(1): 5-22.

Schuman, Howard, and Amy Corning. 2012. Generational Memory and the Critical Period. Public Opinion Quarterly 76(1): 1-31.

Schuman, Howard, and Jacqueline Scott. 1989. Generations and Collective Memories. American Sociological Review 54(3): 359-381.

Schwartz, Barry. 1982. The Social Context of Commemoration: A Study in Collective Memory. Social Forces 61(2): 374-402. 
Shaw, Rosalind. 2010. Afterword: Violence and the Generation of Memory. In Remembering Violence. Anthropological Perspectives on Intergenerational Transmission, eds. N. Argenti and K. Schramm, 251-260. New York, NY: Berghahn.

Sorabji, Cornelia. 2006. Managing Memories in Post-War Sarajevo: Individuals, Bad Memories, and New Wars. The Journal of the Royal Anthropological Institute 12(1): 1-18.

2008. Bosnian Neighbourhoods Revisited: Tolerance, Commitment and Komšiluk in Sarajevo. In On the Margins of Religion, eds. F. Pine and J.D. Pina-Cabral, 97-112. New York: Berghahn Books.

Spasić, Ivana. 2012. Yugoslavia as a Place for Living a Normal Life: Memories of Ordinary People in Serbia. Jugoslavija kao mesto normalnog života: Sećanja običnih ljudi u Srbiji 54(4): 577-594.

Tannock, Stuart. 1995. Nostalgia Critique. Cultural Studies 9(3): 453-464.

Tilly, Charles. 1994. Afterword: Political Memories in Space and Time. In Remapping Memory: The Politics of Time and Space, ed. J. Boyarin, 241-256. Minneapolis: University of Minnesota Press.

Todorova, Maria. 1997. Imaging the Balkans. Oxford: Oxford University Press. Tonkin, Elizabeth. 1992. Narrating Our Past: The Social Construction of Oral History. Cambridge: Cambridge University Press.

Torsti, Pilvi. 2003. Divergent Stories, Convertent Attitudes: Study on the Presence of History, History Textbooks, and the Thinking of Youth in Post-War Bosnia and Herzegovina. Dissertation, Faculty of Social Sciences, University of Helsinki. . 2004. History Culture and Banal Nationalism in Post-War Bosnia. Southeast European Politics 5(2-3): 142-157.

Trouillot, Michel-Rolph. 1995. Silencing the Past: Power and the Production of History. Boston: Beacon Press.

Velikonja, Mitja. 2009. Lost in Transition: Nostalgia for Socialism in PostSocialist Countries. East European Politics and Societies 23(4): 535-551.

Verdery, Katherine. 1999. The Political Lives of Dead Bodies: Reburial and Postsocialist Change. New York: Columbia University Press.

Vertovec, Steven. 2007. Super-Diversity and Its Implications. Ethnic and Racial Studies 30: 1024-1054.

ed. 2014. Migration and Diversity. Cheltenham Glos and Northampton, MA: Edward Elgar Publishing.

Vertovec, Steven, and Alisdair Rogers. 1995. Introduction. In The Urban Context: Ethnicity, Social Networks and Situational Analysis, eds. A. Rogers and S. Vertovec, 1-33. Oxford: Berg.

. 1998. Muslim European Youth: Reproducing Ethnicity, Religion, Culture, Research in Ethnic Relations Series. Aldershot: Ashgate. 
Vetters, Larissa. 2007. The Power of Administrative Categories: Emerging Notions of Citizenship in the Divided City of Mostar. Ethnopolitics 6(2): 187-209.

- 2009. Borders Created from within - Negotiating and Appropriating Residence Registration and Population Statistics in Postwar Bosnia and Herzegovina. EastBordNet COST Action IS0803, Working Paper. Manchester, UK. Vidaković, Petrov. 1989. Memory and Oral Tradition. In Memory: History, Culture and the Mind, ed. T. Butler. Oxford: Basil Blackwell.

Volcic, Zala. 2007. Scenes from the Last Yugoslav Generation: The Long March from Yugo-Utopia to Nationalisms. Cultural Dynamics 19(1): 67-89.

Welzer, Harald. 2007. Der Krieg der Erinnerung: Holocaust, Kollaboration and Widerstand im europäischen Gedächtnis. Frankfurt/Main: FischerTaschenbuch-Verlag.

- 2010. Re-Narrations: How Pasts Change in Conversational Remembering. Memory Studies 3(1): 5-17.

Welzer, Harald, Sabine Moller, Karoline Tschuggnall, Olaf Jensen, and Torsten Koch, eds. 2005. Opa war kein Nazi: Nationalsozialismus und Holocaust im Familiengedächtnis. Frankfurt/Main: Fischer.

Wessendorf, Susanne. 2007. "Roots Migrants": Transnationalism and 'Return' among Second-Generation Italians in Switzerland. Journal of Ethnic and Migration Studies 33(7): 1083-1102.

Wimmen, Heiko. 2004. Territory, Nation and the Power of Language: Implications of Education Reform in the Herzegovinian Town of Mostar. GSC Quarterly Report 11: 1-21.

Wood, David. 1991. Introduction: Interpreting Narrative. In On Paul Ricoeur: Narrative and Interpretation, eds. D. Wood and P. Ricouer, 1-19. London: Routledge.

Yurchak, Alexei. 2005. Everything Was Forever, Until It Was No More: The Last Soviet Generation. Princeton, NJ: Princeton University Press.

Open Access This chapter is distributed under the terms of the Creative Commons Attribution 4.0 International License (http://creativecommons.org/licenses/by/4.0/), which permits use, duplication, adaptation, distribution, and reproduction in any medium or format, as long as you give appropriate credit to the original author(s) and the source, a link is provided to the Creative Commons license, and any changes made are indicated.

The images or other third party material in this chapter are included in the work's Creative Commons license, unless indicated otherwise in the credit line; if such material is not included in the work's Creative Commons license and the respective action is not permitted by statutory regulation, users will need to obtain permission from the license holder to duplicate, adapt or reproduce the material.

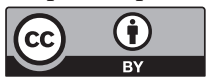

